\title{
Intensive Pedestrian Survey of the Phase II Portion of the Medina River Park Trail, Bexar County, Texas
}

Antonia L. Figueroa

Center for Archeological Research, University of Texas at San Antonio

Follow this and additional works at: https://scholarworks.sfasu.edu/ita

Part of the American Material Culture Commons, Archaeological Anthropology Commons, Environmental Studies Commons, Other American Studies Commons, Other Arts and Humanities Commons, Other History of Art, Architecture, and Archaeology Commons, and the United States History Commons

Tell us how this article helped you.

This Article is brought to you for free and open access by the Center for Regional Heritage Research at SFA ScholarWorks. It has been accepted for inclusion in Index of Texas Archaeology: Open Access Gray Literature from the Lone Star State by an authorized editor of SFA ScholarWorks. For more information, please contact cdsscholarworks@sfasu.edu. 
Intensive Pedestrian Survey of the Phase II Portion of the Medina River Park Trail, Bexar County, Texas

\section{Creative Commons License}

\section{(c) (i) (9)}

This work is licensed under a Creative Commons Attribution-NonCommercial 4.0 International License 


\section{Intensive Pedestrian Survey of the Phase II Portion of the Medina River Park Trail, Bexar County, Texas}

by

Antonia L. Figueroa

Texas Antiquities Permit No. 4769

Prepared for:

Halff Associates, Inc.

4030 West Braker Lane, Suite 450

Austin, Texas 78759

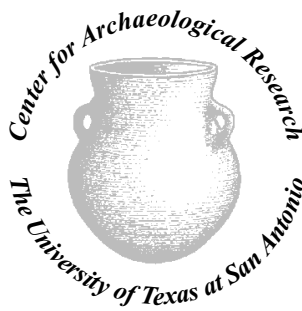

(C)2008
Prepared by:

Center for Archaeological Research The University of Texas at San Antonio Archaeological Report, No. 394 


\title{
Intensive Pedestrian Survey of the Phase II Portion of the Medina River Park Trail, Bexar County, Texas
}

\author{
by
}

Antonia L. Figueroa

Texas Antiquities Committee Permit No. 4769

Principal Investigator

Jennifer L. Thompson

Prepared for:

Halff Associates, Inc.

4030 West Braker Lane, Suite 450

Austin, Texas 78759

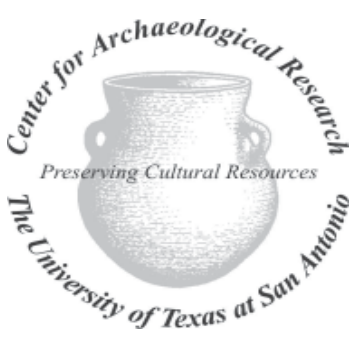

(C) 2008
Prepared by:

Center for Archaeological Research The University of Texas at San Antonio Archaeological Report No. 394 



\begin{abstract}
The Center for Archaeological Research at The University of Texas at San Antonio performed an intensive pedestrian survey of the Phase II portion of the Medina River Park Trail, Bexar County, Texas in January 2008. The proposed Phase II trail corridor starts at Applewhite Road and runs approximately 3.75 miles to the vicinity of Neal Road, south of the Medina River. Eight previously recorded sites were revisited during the archaeological investigations that include 41BX545, 41BX546, 41BX533, 41BX531, 41BX537, 41BX538, 41BX833 and 41BX831. No new sites were encountered during the archaeological survey. The portions of the State Archaeological Landmark sites that were investigated by CAR did not contribute to their eligibility status. Current land use of the area by the American Indians in Texas at the Spanish Colonial Missions (AIT-SCM) was documented in the environs of 41BX531. The utilization of the land for activities should be regulated as not to impact cultural resources. All materials recovered during the investigations and all project related documents are curated at the Center for Archaeological Research.
\end{abstract}




\section{Table of Contents}

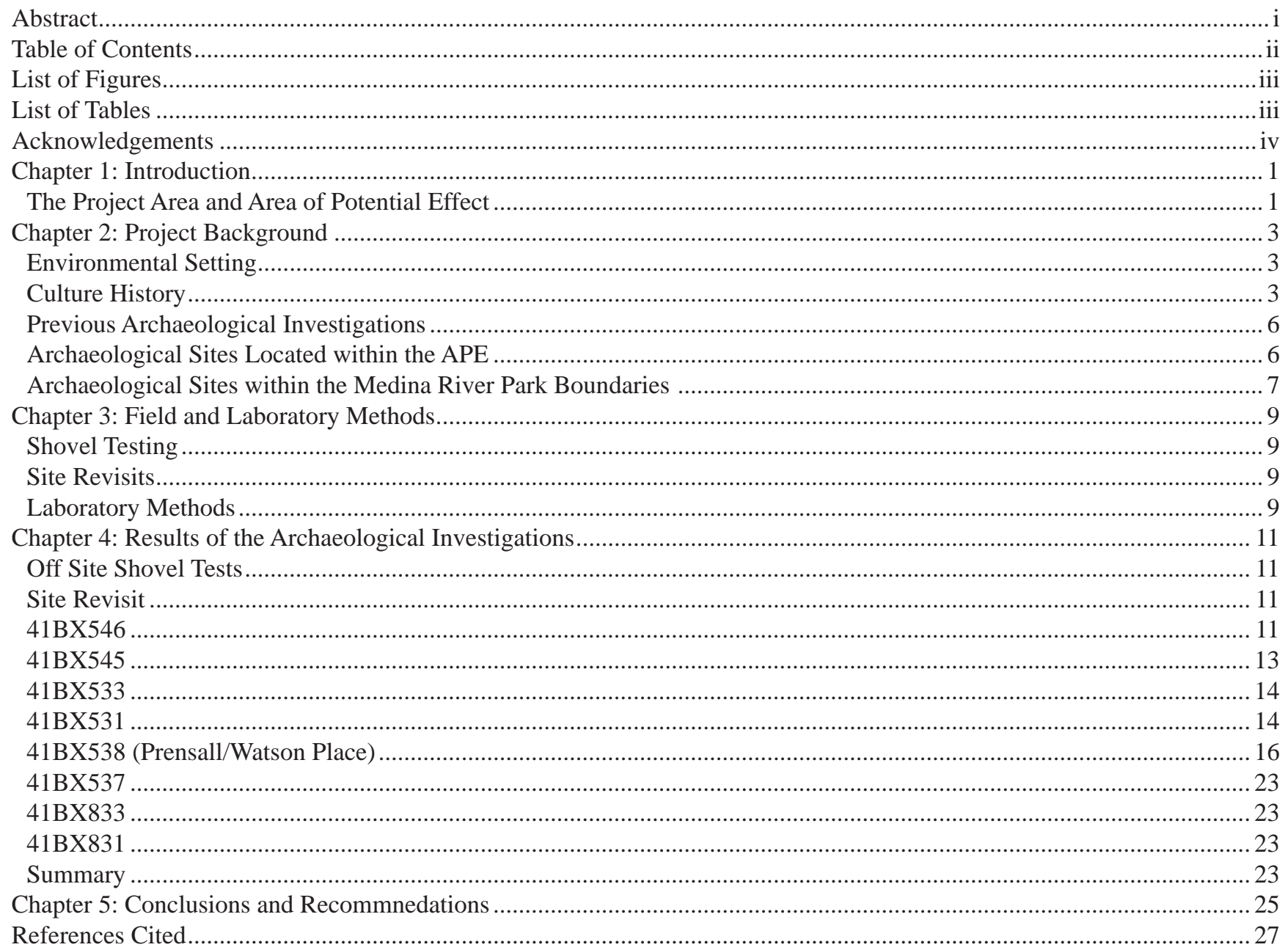




\section{List of Figures}

Figure 1-1. The location of the project area in southwest Bexar County. ....................................................................... 1

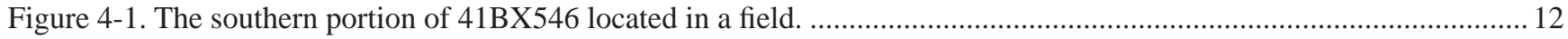

Figure 4-2. Shovel test locations on 41BX546 and extended site boundary (dashed line)................................................ 12

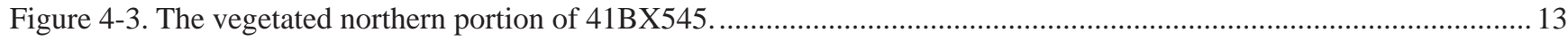

Figure 4-4. The southern portion of 41BX545 located in a field. ............................................................................... 13

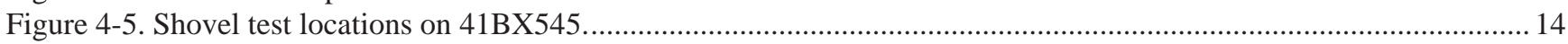

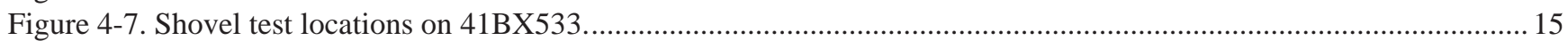

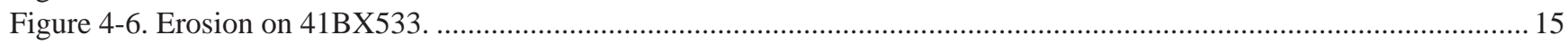

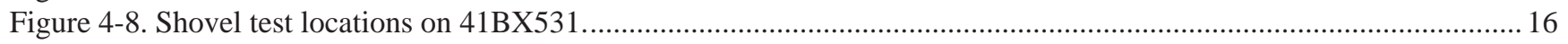

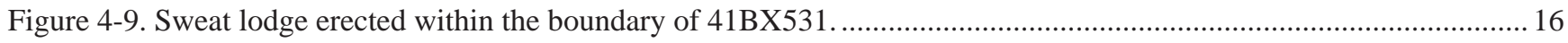

Figure 4-10. Shovel test locations on 41BX538 and outbuildings............................................................................... 17

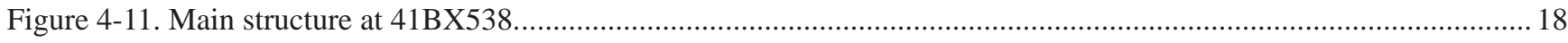

Figure 4-12. Pigeon coop 1 (Outbuilding 1) moved from 41BX681 to 41BX538................................................................. 18

Figure 4-13. Pigeon coop 2 (Outbuilding 2) moved from 41BX681 to 41BX538............................................................... 19

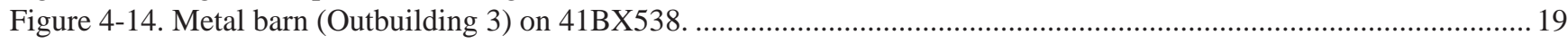

Figure 4-15. Metal shed (Outbuilding 4) adjacent to metal barn on 41BX538.................................................................2 20

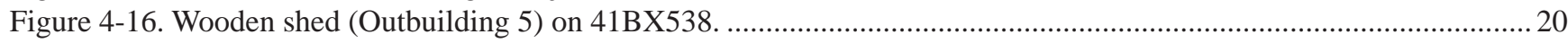

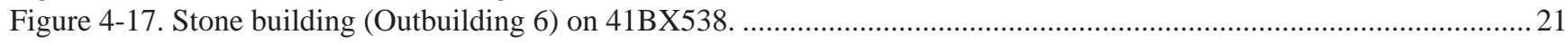

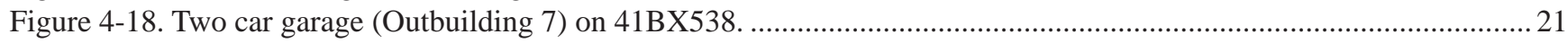

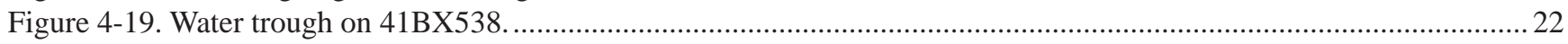

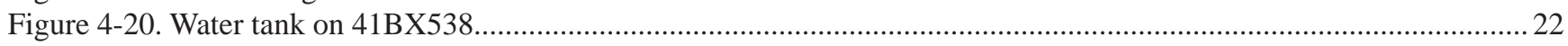

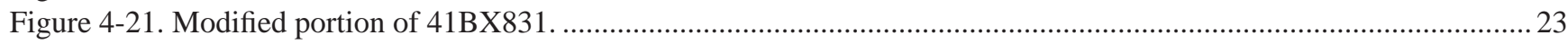

\section{List of Tables}

Table 4-1. Shovel Tests Excavated on Previously Recorded Sites ........................................................................... 11

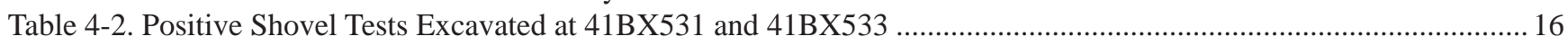

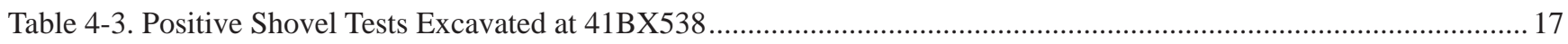




\section{Acknowledgements}

The author would like to thank all the individuals that made the completion of this project possible. The field crew consisted of Nathan Devito, Cyndi Dickey, Jon Dowling, Jason Perez and Joseph Thompson. Wayne Cooper and Tim Urban of Halff Associates Inc. provided CAR with project details and GIS data. Thanks to Kay Hindes of the City of San Antonio Historic Preservation Office. Jennifer L. Thompson, the Principal Investigator, aided with field work logistics and provided comments during the drafting of the report. Dr. Steve Tomka and Dr. Raymond Mauldin were supportive throughout all stages of the project. 


\section{Chapter 1: Introduction}

The Center for Archaeological Research at The University of Texas at San Antonio (CAR-UTSA) conducted a 100 percent intensive pedestrian survey of the Phase II portion of the Medina River Park Trail, Bexar County, Texas (Figure 1-1). To comply with the requirements of the Antiquities Code of Texas, Halff Associates Inc. contracted CAR to conduct the archaeological investigations of the Phase II portion of the proposed Medina River Park Trail. Halff Associates Inc., of Austin is providing planning, design and construction activities in support of the planned Medina River Park Trail for the Parks and Recreation Department of the City of San Antonio. Archaeological investigations were conducted under Texas Historical Commission (THC) permit \# 4769 with Jennifer L. Thompson serving as Principal Investigator and Antonia L. Figueroa acting as Project Archaeologist.

The proposed trail is the property of the City of San Antonio, a political subdivision of the State of Texas. As such, the project has to comply with state historic preservation laws

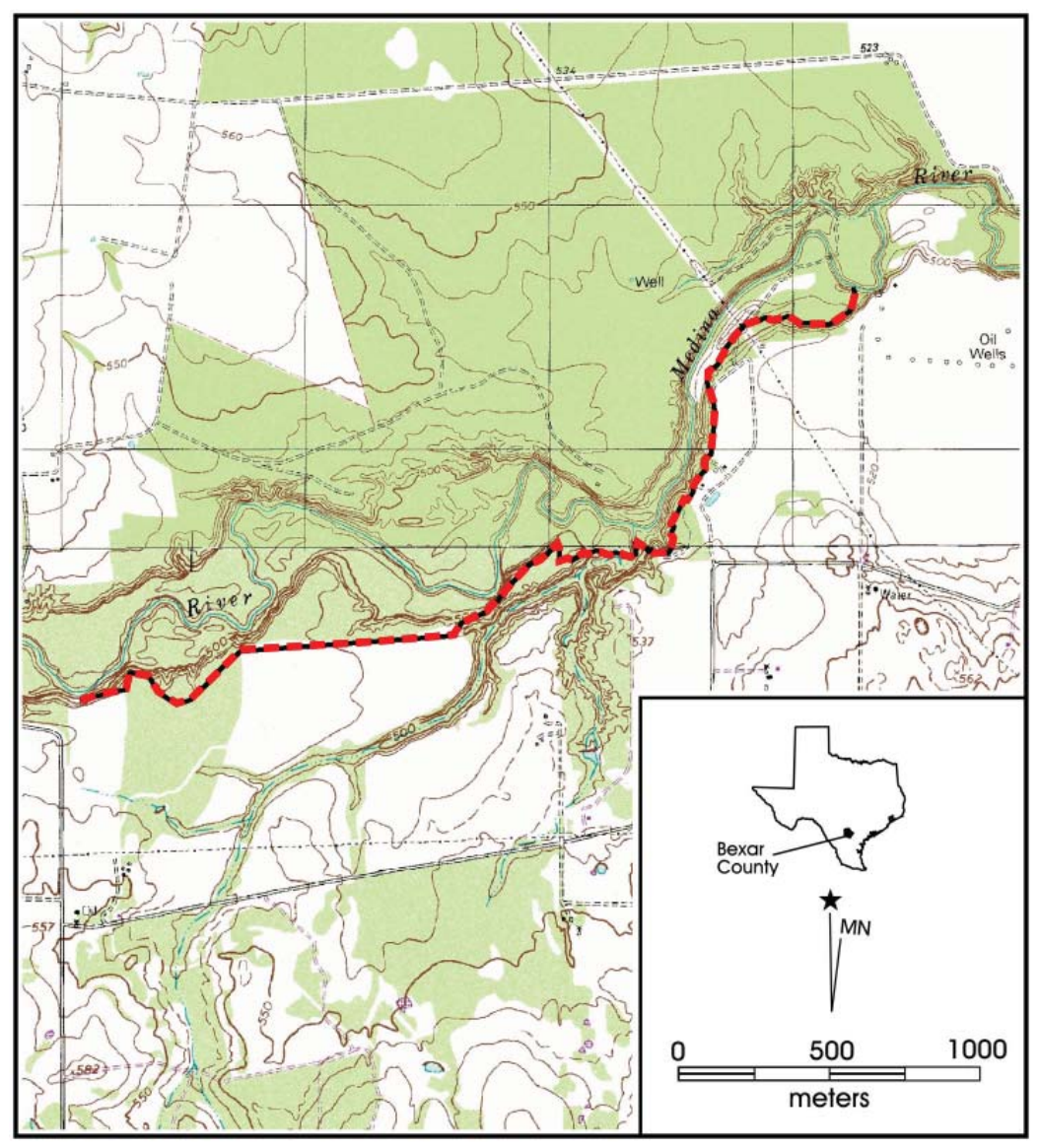

and specifically the mandates of the Antiquities Code of Texas and falls under the oversight of the Texas Historical Commission.

The purpose of the pedestrian survey was to identify all prehistoric and historic properties that may be impacted by the proposed trail alignment and determine the National Register of Historic Places (NRHP) and State Archeological Landmark (SAL) eligibility status of the portion of the sites that will be impacted by the proposed trail. During the course of the intensive pedestrian survey eight previously recorded archaeological sites were revisited and no new sites were identified.

The remainder of this chapter describes the project area and the Area of Potential Effect (APE). Chapter 2 discusses the project background, while Chapter 3 outlines the field and laboratory methods implemented during the project. The results of the archaeological investigations are presented in Chapter 4, followed by a summary and recommendations in Chapter 5.

\section{The Project Area and Area of Potential Effect}

The proposed Medina River Park Trail corridor will be constructed in three phases. The archaeological investigations and this report only focused on the Phase II portion of the proposed trail. The entire proposed trail spans Medina River Park, located east of State Hwy 16 (Poteet Jourdanton Freeway), and continues along the Medina River to Pleasanton Road. Phase II of the trail (the Area of Potential Effect), begins at Applewhite Road and runs approximately 3.75 miles to the vicinity of Neal Road, south of the Medina River. The limits of the project area encompass land north and south of the Medina River, however, the client (Halff Associates, Inc.) contracted CAR to survey only the proposed trail alignment, referred to as the APE in this document. The trail corridor will vary in width between 10 and 13 meters. The proposed impacts from the trail installation along the APE will include grading to a depth of $24 \mathrm{~cm}$ (10").

Figure 1-1. The location of the project area in southwest Bexar County. 
After fieldwork, CAR learned that the project area had been part of a 1200-acre land transfer between the city and the Land Heritage Institute. Kay Hindes (personal communication April 2008) reported to CAR that the project area was no longer owned by the City of San Antonio, but that the new owners, the Land Heritage Institute, had agreed to allow the trail to cross the property as part of the land transfer agreement. The land transfer was not reported to CAR or the city archaeologist during any portion of CAR's Medina River survey. Though CAR has no official data, the inset map for an article published in the San Antonio Current (Wolff 2008) shows the APE lies entirely within the transferred land. All the sites discussed in this report are part of the 1200 acres along the south side of Medina River that was transferred to the Land Heritage Institute. 


\section{Chapter 2: Project Background}

This chapter presents the project area environs and culture history of the region. The Medina River corridor has been subject to archaeological investigations and these previous investigations area presented in this chapter. The archaeological sites that will be impacted by the proposed trail corridor and those sites that are in boundaries of the Medina Park but that will not be impacted by the proposed trial corridor are presented at the end of this chapter.

\section{Environmental Setting}

The project area is located on the Terrell Wells and Thelma 7.5' series USGS quadrangle maps. The project area is situated south of the Edward's Plateau and below the Balcones Escarpment. Elevations in the project area range from 500 to 540 feet amsl. The climate in this region is typically subtropical with cool winters and hot summers (Taylor et al. 1991). Annual temperatures range from an average low of $37.9^{\circ} \mathrm{F}$ in January to an average high of $95.0^{\circ}$ in July (Bomar 1999). Annual average rainfall for San Antonio is 30.98 inches (Bomar 1999).

The project area is situated on the southern banks of the Medina River. The Medina River originates in Bandera County within the Edwards Plateau region and continues southeast into the Balcones Escarpment where it joins with the San Antonio River (Greaves et al. 2004).

Soils that are found in the project area are of the Venus Frio Trinity association and are deep calcareous soils found on bottomlands and terraces (Taylor et al. 1991). Particular soils series within this association include Venus clay loam, which is a level to gently sloping soil with deep to moderate dark color and found on terraces or alluvial fans. This soil series is productive and as a result much of it has been cultivated. The Frio soil series mostly occurs on floodplains of the Medina River on uneven surfaces and tends to be dissected by partly filled old stream channels. Gully lands occur along the high terraces of river and streams. Severe gulling and sheet erosion are common in this soil series.

\section{Culture History}

This section summarizes the culture history for the region. Due to the presence of both prehistoric and historical sites in the project area this discussion includes the Paleoindian through historical period of Texas.

\section{Paleoindian (11500-8800 B.P.)}

The Paleoindian period corresponds with the earliest documentation of humans in Bexar County and occurred between 11500-8800 B.P(Collins 1995). Subsistence patterns during this time focused on large, highly mobile mega fauna. This period is typically divided into early and late subperiods. The early portion of the period is associated with Clovis and Folsom adaptations. Lithic technology includes fluted Clovis and Folsom projectile points during the early part of this period. In the later portion of the period there were stylistic changes in projectile point technology seen in Dalton, Scottsbluff, and Golondrina traditions. While widespread in geographic range, these types occurred in high densities in the High Plains and Central Texas (Meltzer and Bever 1995). As the climate warmed, megafauna gradually died off, and subsistence patterns shifted.

\section{Archaic (8800-1200 B.P.)}

This period is subdivided into the Early, Middle and Late subperiods. The subperiods are distinguished by differences in climate conditions, resource availability, subsistence practices and diagnostic projectile points (Collins 1995). Plant gathering appears to have become an important part of subsistence strategies during this period, and was probably even more important during xeric periods. This may explain the appearance of burned rock earth ovens during the period. They were used to cook a variety of plant foods that were otherwise inedible, such as the roots of sotol, and yucca (Collins 1995: 383).

In the Early Archaic (8800-6000 B.P.) there was a shift in subsistence from large game hunting to plant foods and medium and small species (Collins 1995). Projectile point styles include Angostura and Early Split Stemmed. Taskspecific tools include Clear Fork gouges and Guadalupe and Nueces bifaces (Turner and Hester 1993:246, 256). Early Archaic sites are located along the eastern and southern portions of the Edwards Plateau in areas with reliable water sources (McKinney 1981). Population densities were relatively low during this subperiod and consisted of small highly mobile bands (Story 1985:39).

The Middle Archaic spans from 6000 to 4000 B.P. (Collins 1995). Diagnostic projectile points from this sub-period include Bell, Andice, Taylor, Nolan, and Travis. According to Collins (1995) during the Middle Archaic there was a focus on large-game hunting of bison. However, recent studies suggest an absence of bison during the Middle Archaic (Mauldin and 
Kemp 2005). Climate was gradually drying as the onset of the Altithermal drought began. Demographic and cultural change likely occurred in response to these hotter and drier conditions.

The last subperiod of the Archaic is the Late Archaic that spans 4000 to 1200 B.P. (Collins 1995). Dart point diagnostics of the Late Archaic are triangular points with corner notches that include Ensor and Ellis (Turner and Hester 1993:114,122). Other Late Archaic projectile points are Bulverde, Pedernales, Marshall, and Marcos types (Collins 1995). Evidence from the Thunder Valley sinkhole cemetery suggests that territoriality may have established during the Late Archaic, possibly as a result of population increase (Bement 1989). Some researchers state the accumulation of burned rock middens ceased at this time though current research has challenged this notion (Black and Creel 1997; Mauldin et al. 2003).

\section{Late Prehistoric (1200-350 B.P.)}

The Late Prehistoric period is marked by the Austin and Toyah phases. During the Austin Phase the bow and arrow was introduced. Nickels and Mauldin (2001) suggested at the beginning of this period environmental conditions were warm and dry. More mesic conditions appear to accelerate after 1,000 B.P. Subsistence practices remain relatively unchanged, especially during the Austin Phase. The Austin Phase of the Late Prehistoric may represent the most intensive use of burned rock middens (Black and Creel 1997), and includes diagnostic point types Scallorn and Edwards (Collins 1995; Turner and Hester 1993).

The presence of bone tempered ceramics (Leon Plain) during the Toyah Phase suggests interaction between Central Texas and ceramic producing traditions in East and North Texas (Perttulla et al. 1995). Ceramics were in common use in East Texas by 2450 B.P., but the first Central Texas wares did not appear until ca. 650-700 B.P. Other technological traits of this phase include the diagnostic Perdiz point and beveled bifaces. These specialized processing kits are thought to be an adaption to flourishing bison populations by some (Ricklis 1992) and a sign of intensification of declining bison populations by others (Mauldin et al. 2006).

\section{Protohistoric (ca. 1528-1700)}

The Protohistoric period is a term typically used to describe the transition between the Late Prehistoric and the Colonial period. This period is not well documented archaeologically in Texas. Some researchers (Wade 2003) argue that the Protohistoric period may coincide with the end of the Late Prehistoric Toyah Interval, spanning the period of A.D. 1250/1300 to A.D. 1600/1650 (Hester 1995). For the purposes of this report we define the period as beginning with the Early Spanish explorations in Texas (ca. 1528) and ending with the establishment of a strong Spanish presence in the region in the late 1600 s and early 1700 s.

During this period, there was intermittent contact between the native groups and Spanish explorers. It was a time before the Spanish economy significantly impacted the indigenous groups in the area. A number of encounters between the indigenous communities and Europeans were recorded during this period, including those of Cabeza de Vaca (15281536) and the French settlement established by Rene Robert Cavelier, Sieur de La Salle (1685-1689). The Spanish sent General Alfonso de Leon into the area in 1689, and in 1691 the area of present-day San Antonio was first visited by Domingo de Teran.

Archaeologically, the time period is poorly documented but has been identified at several sites in south Texas counties (e.g., Hall et al. 1986; Inman et al. 1998; Mauldin et al. 2004). A problematic issue concerning this time period is that there is not a clear set of material culture associated with the period. Therefore, it is difficult to document this time period archaeologically without absolute dates. Sites that have been deemed as "Protohistoric" may have Late Prehistoric and/or Historic artifacts associated with them, and in several cases radiocarbon dates confirm their Protohistoric designation (Mauldin et al. 2004).

\section{The Colonial and Mission Periods in San Antonio (ca. 1700-1800)}

The first Spanish presidios in North America began to appear in 1565 with the establishment of San Agustin on the Atlantic coast of Florida (Moorhead 1991:27). The establishment of the presidios was mainly due to the encroachment of European powers, predominantly the French (Moorhead 1991:27). The first attempt to have an established Spanish presence in Texas was the founding of Mission San Francisco de los Tejas, established in 1690 near Nacogdoches, and Santismo Nombre de Maria, built on the banks of the Neches River in that same year. Both attempts were short-lived, and by 1693, both were adandoned (Fox and Cox 2000). The founding of Mission San Juan in 1700 along the Rio Grande marked the beginning of an established Spanish presence in the region (Weddle 1968).

In 1718, Don Martín del Alarcón established Presidio San Antonio de Béxar and Mission San Antonio de Valero near the headwaters of San Pedro Creek (Fox 1997, after Chipman 1992:14; Hoffman 1937). In 1722, Marqués de Aguayo relocated the villa and presidio to their final locations on the west side of the San Antonio River. The presidio and the villa 
were named after the Duke of Béjar, the elder brother of the Viceroy (Buerkle 1976:50). The purpose of the San Antonio de Bexar presidio was not only to protect the mission, town, farms and ranches, but also serve as a way-station between Mexico and the East Texas settlements. After a four-month stay in East Texas, Alarcón returned to San Antonio where he faced challenges and problems with the missionary fathers (Buerkle 1976:51). After his request for additional soldiers, funds, and supplies was denied, Alarcón resigned from his position in 1719 (Buerkle 1976:51).

In 1719, Marqués de San Miguel de Aguayo became the governor and captain general of Coahuila and Texas. He led an expedition into Texas to return Spanish presence to the frontier. Aguayo and his troops re-supplied in San Antonio before returning to East Texas for eight months. While in East Texas, Aguayo re-established the presidios and installed new missions (Buerkle 1976:52). Upon his return to San Antonio, he found that the granary at the presidio, along with several of the soldiers' jacales, had been destroyed by fire. Aguayo ordered that a new presidio be built of adobe. Harsh weather delayed the progress of the new presidio and it was apparently never completed. The construction never "progressed beyond two towers, a surrounding wall and some scattered wooden or jacal structures” (Fox 1997:2: after Buckley 1991).

In 1720, Mission San José y San Miguel de Aguayo was established in the area, followed by the missions Nuestra Señora de la Purisima Concepción de los Hainai, San Francisco de Espada and San Juan Capistrano. The establishment of Villa de San Fernando occurred in 1731. The settlement was to be home to Canary Islanders (Isleños). The villa became the first civilian settlement of Texas.

The Seven Year War began in 1756 and changed the dynamics of Spanish colonialism in Texas. The British replaced the French as a major threat to Spanish presence, and Spain had to fortify its settlements in Louisiana and California against indigenous groups. As a result of this shift in focus, East Texas settlements began to deteriorate and populations were relocated to San Antonio. During the later part of the eighteenth century, the missions in San Antonio began to decline due to a shortage of priests and a decline in population and workers to maintain the agricultural fields.

In 1790, Manuel Silva, under the College of Zacatecas, recommended that Mission San Antonio de Valero be secularized. Furthermore, of the four remaining missions only two were still functioning. By 1794, Mission San Antonio de Valero was secularized and the surrounding lands distributed to the remaining Mission Indians and other individuals.

\section{Early Texas (1800-1836)}

In 1802 the Compania Volante de San Carlos del Alamo de Parras from Coahuila occupied the Presidio de San Antonio de Béxar (Cox 2005). The soldiers were assigned quarters in the abandoned Mission San Antonio. It was at this time that the former mission became known as the Alamo.

Discontent with New Spain in the northern provinces led to the Hidalgo revolt in 1810. Mexico became independent from Spain in 1821. The 1824 constitution merged Texas and Coahuila into one state, with San Antonio de Béxar as a separate department (Fox et al. 1997).

Spain's attempt to regain control of Mexico in 1829 failed. Stephen F. Austin asked San Antonio to provide support for his efforts to make Texas a separate entity in 1833. In 1833, Santa Ana became the President of Mexico.

General Cós and his troops were pushed out of San Antonio under Ben Milam in December of 1835. The Mexican army arrived in San Antonio in February 1836 and the Alamo and Texan troops were assaulted and defeated in early March of 1836. Santa Anna was finally defeated and caught at the Battle of San Jacinto later that same year (Fox et al. 1997).

\section{The Republic of Texas (1836-1845)}

Sam Houston was inaugurated as the first president of the Republic of Texas in 1836. The Texas Congress set the boundaries for the newly formed republic (Nance 2004). The Rio Grande was declared the southern boundary and Louisiana the eastern border. The population of San Antonio increased due to immigration. The new city council of San Antonio elected John W. Smith as mayor in 1837.

Mexico refused to recognize the independence of Texas and a formal state of war continued. General Rafael Vasquez, with 700 soldiers, attempted to take over San Antonio and the unprepared Texan force retreated to present-day Seguin. In 1842, a friend of Santa Ana, General Adrian Woll, captured San Antonio, and this time the Texans resisted. Finally, in 1844 a truce was called between Mexico and Texas (Fox et al. 1997).

\section{The State of Texas (1845-1900)}

On December 29, 1845, the United States Congress approved the Texas State Constitution and Texas was admitted as a state. This act, coupled with the failure to agree on the Rio Grande as a boundary and on the sale of California to the United States, resulted in the war between the United States and Mexico (1846-1848). In early 1846, General Zachary 
Taylor advanced to the Rio Grande, occupying land that the Mexican government viewed as its own, and war was declared in May of that year. After a series of battles, the United States military occupied Mexico City in August of 1847. In May of 1848, the ratification of the Treaty of Guadalupe Hidalgo by the Mexican government signaled the end of hostilities, established the Rio Grande as a boundary, and gave the United States present-day Arizona, California, New Mexico, Texas and parts of Colorado, Nevada and Utah in exchange for $\$ 15$ million. United States troops left Mexico in June of that same year (Bauer 1974; Wallace 1965).

With the boundaries of Texas now established, the new state soon found itself embroiled in controversy over its position on slavery. The majority of the population within the state was derived from the south, and while ranching and subsistence farming were probably the major economic activities, cottonbased agriculture was the major cash crop. In 1846, Texas had more than 30,000 black slaves, many associated with cotton production. At the breakout of the Civil War, thousands of Texans fought on both sides, with the effects of the war seen throughout Texas, including shortages of commodities in San Antonio. On June 19, 1865, General Gordon Granger arrived in Galveston with Union forces, signaling the end of the Civil War (Fox et al. 1997).

In February 1877, the Galveston, Harrisburg and San Antonio Railroad arrived in the area. With the arrival of the railroad, commercial elements were introduced into the area for the first time (Fox et al. 1997). A growth in business was created near the depot, including stores and saloons. City waterworks also commenced during this time and the city continued to expand. At the beginning of the twentieth century, the population of San Antonio was just over 53,000 (Fox et al. 1997).

\section{Previous Archaeological Investigations}

Several archaeological projects have been conducted in the project area environs by CAR. In 1981 and 1984, CAR conducted archaeological investigations as part of the Applewhite Reservoir Project (McGraw and Hindes 1987). Portions of this area were re-examined in 2003 in preparation for the Toyota Motor Manufacturing Plant (Greaves et al. 2004; Weston 2004). The Medina River Park project was also conducted in the vicinity by CAR in 2003 (Figueroa and Tomka 2004). The Center for Ecological Archaeology (Texas A\&M University) also performed archaeological investigations at many of the sites in the area (Adovasio and Green 2003; Thoms and Mandel 2005). SWCA Environmental consultants have conducted archaeological surveys and testing in the area as well (Barile et al. 2003; Barile and Miller 2003). There are eight previously recorded sites in the APE and 15 previously recorded sites are within the boundaries of the Medina River Park but not in the APE.

\section{Archaeological Sites Located within the APE}

Within the APE there are eight previously recorded sites (41BX545, 41BX546, 41BX533, 41BX531, 41BX537, 41BX538, 41BX833, and 41BX831). Three of the sites have been designated as State Archeological Landmarks (41BX538, 41BX833 and 41BX831). Below is a description of each site that will be potentially impacted by the proposed trail.

41BX545 was identified in 1981 and is located on the southern upper terrace of the Medina River (approximately 100 meters to the north). The site was described as a light scatter of chipped stone and burned rock. The site was reported as moderately to severely disturbed by natural erosion and deep plowing in the southern portion (McGraw and Hindes 1987: 198). The site was reassessed in 1984. The reassessment suggested that buried components may be present at the location. It was recommended that further work be performed on the site (McGraw and Hindes 1987; THC 2008).

41BX546 is located along the southern terrace of the Medina River (McGraw and Hindes 1987:199). The site consisted of lithic debitage, core fragments, burned rock and mussel shell fragments at the time of recording. Further work was not recommended at 41BX546 in 1981 but a reassessment of the site in 1984 suggested buried deposits may be present in the area (McGraw and Hindes 1987:199).

41BX533 is situated south of an arroyo complex south of the Medina River on a high terrace and will be intersected by the proposed trail. The site consisted of lithic debitage an Early Triangular biface, burned rock and mussel shell (McGraw and Hindes 1987:178). Cultural material was observed within eroding gullies along the slope of the occupation area. Due to severe gully erosion and land clearing activities further work at the site was not recommended, it was suggested that the site was not eligible for listing on the NRHP.

Site 41BX531 is located south of the Medina River on a high terrace, northwest of Neal Road. The Texas Archeological Sites Atlas has site records from TAMU that indicate that shovel tests, backhoe trenches and test units were excavated on the site in 1999 (THC 2008). The site consists of a fallen historic structure and a prehistoric component. The prehistoric component contained lithic debitage, mussel shell, burned rock and a Late Prehistoric biface. The deposits appear to 
extend to a depth of 80 centimeters below surface (cmbs). Radiocarbon assays from a hearth feature dated to $790 \pm 110$ BP (THC 2008). According to the Texas Archeological Sites Atlas, mitigation was recommended for this site.

41BX537 is the prehistoric component of 41BX538 and consists of lithic debitage, burned rock and temporally diagnostic lithic tools (Perdiz and Ensor). It appears that the site will be impacted by the proposed trail. The site has been disturbed by plowing activities and monitoring of the site was recommended (McGraw and Hindes 1987:184).

41BX538 was identified in 1981 and was later designated SAL. The site was originally described as two historical structures: a large two-story frame building and a second smaller structure of cut stone and adobe (McGraw and Hindes 1987:184). In 1984 the Corps of Engineers recommended limited testing of the site. Extensive archival research was conducted on the property. TAMU investigated the site in 1990 and documented the two-story frame and stone dwelling, along with various outbuildings (Adovaiso and Green 2003). The property was originally a part of the Ygnacio Perez Spanish Colonial land grant. The site was deemed eligible under NRHP Criterion D.

41BX833 is listed as a SAL and the proposed trail will intersect the site. The SAL form describes the site as consisting of a prehistoric camp and historic chimney. It is located near the intersection of Neal Road and Applewhite Road, roughly 60 meters past 41BX538 (THC 2008). Information on the prehistoric component was difficult to encounter. In the TAMU report, the prehistoric component is extensive, though the Texas Archeology Sites Atlas reports only a few flakes (THC 2008). The historic component consists of a chimney and all that remains is an outline of sandstones that measure $1 \mathrm{~m}$ x $2 \mathrm{~m}$ (Adovaiso and Green 2003). Recovered cultural material suggested the feature dated to the late nineteenth or early twentieth century. TAMU assessed the site between 1989 and 1990 (Adovasio and Green 2003). The historic feature was not considered eligible for listing on the NRHP.

41BX831 (the Richard Beene site) will be crossed by the proposed trail and has been designated as a SAL. The site is located on an upper terrace southwest of the Medina River. It contains a prehistoric and historic component. TAMU performed intensive excavations on the prehistoric component of the site mostly during the construction of the Applewhite dam footprint (Thoms and Mandel 2005). The site contains well stratified deposits that represent Early, Middle and Late Archaic, as well as Late Prehistoric occupations. The historic components of the site included an early to late twentiethcentury residence with outbuildings, middens and dismantled chimney (Adovasio and Green 2003). The historic remains were not recommended as eligible for listing on the NRHP.

\section{Archaeological Sites within the Medina River Park Boundaries}

Site 41BX539 is listed as a SAL and is located north of Neal Road, 300 meters south of the Medina River. Lithic debitage, tools and burned rock were encountered on the site. Portions of the site have been disturbed by land clearing and natural erosion (McGraw and Hindes 1987), although the western reaches of the site may be less disturbed. Further work was recommended at the site which is potentially eligible for NRHP listing.

Site 41BX669 is located south of Medina River and is listed as a SAL (THC 2008). To the west of the site is a major arroyo complex. Cultural material observed on the site includes a scatter of lithic debitage and burned rock (McGraw and Hindes 1987:242). Late Prehistoric and Late Archaic diagnostics were also recorded on the surface. TAMU tested the site and further work was recommended. The site is potentially eligible for listing on the NRHP.

41BX661 is a multi-component site that contains a historic structure and a prehistoric campsite (Barile and Miller 2003). The site was first recorded in 1984 (McGraw and Hindes 1987:223) and revisited numerous times since (Greaves et al. 2004:84). When CAR revisited the site in 2003, all features recorded in 1984 had been removed with the exception of the structure (Greaves et al. 2004). In 2003, CAR had not recommended the site for official designation as a SAL nor for nomination to the NRHP. Most recently, 41BX661 was tested by SWCA (Barile and Miller 2003). The site was not recommended for listing as a SAL.

East of 41BX661 is 41BX662 which was first recorded in 1981 and is located on an eroding terrace complex, adjacent to the flood plain of the Medina River (McGraw and Hindes 1987:225). The site consists of a brick kiln that was used to manufacture bricks for construction of the Linn-Walsh structure (41BX681). The site has been designated as a SAL but will not be impacted by the proposed trail. The site was revisited by CAR in 2003 and 20 shovel tests were excavated (Greaves et al. 2004:87). Further testing was recommended at the site.

Site 41BX657 was identified during the Applewhite survey and is located on high bluff on the north bank of the Medina River (McGraw and Hindes 1987:219). The site consisted of a light scatter of lithic debris. Slope erosion was noted 
along the bluff margins and further work on the site was not recommended by McGraw and Hindes (1987). The site will not be impacted by the proposed trail alignment. CAR revisited the site in 2003 and excavated 20 shovel tests; all proved to be negative and only two surface finds were noted at the site (Greaves et al. 2004:80).

41BX652 is located north of Medina River and will not be affected by the proposed trail. It is listed as a SAL. The site is situated on the north bank of the Medina River along a former terrace (McGraw and Hindes 1987:214). It consists of a scatter of burned rock, lithic debitage and diagnostic materials (Langtry and Edgewood projectiles points and Leon Plain ceramic sherds). Portions of the site have been affected by erosion. Subsurface testing was recommended.

Located north of 41BX652 is site 41BX653 also north of Medina River, where the Phase II portion of the proposed trail will not be located. The site has been designated as a SAL. Several eroded burned rock clusters were found scattered across the site (McGraw and Hindes 1987:215). Lithic debitage and a Montell projectile point were collected. Subsurface testing of the site was recommended by McGraw and Hindes (1987). CAR revisited the site in 2003 as part of the Starbright Project (Greaves et al. 2004:71). Out of the forty shovel tests, only four were positive. It was suggested that materials from the site have eroded down slope. New site boundaries were drawn. Further work was not recommended and the site was judged not eligible for listing to the NRHP.

41BX349 was identified as an Anglo-Texan farmstead (18301860) located north of Medina River. The site consisted of a chimney fall and piers. The site was revisited in 2003 by CAR (Greaves et al. 2004:76). Cultural material (historic and prehistoric) encountered in shovel tests was sparse and no intact features were found. Further work was not recommended and the site was not considered eligible for designation as a SAL nor listing on the NRHP.

During the initial recording, site 41BX656 was thought to be a multi-component prehistoric site (McGraw and Hindes 1987:218). At the time of CAR's revisit in 2003, a moderate scatter of lithics and burned rock were reported (Greaves et al. 2004:73). Artifact densities were low and no intact features were identified. It was recommended that the site was not eligible for designation as an SAL or listing to the NRHP.

Site 41BX658 was first identified in 1987 and is located north of Medina River. At that time, it was being impacted by erosion and two ranch roads that traversed the site. In 2003, CAR revisited the site and excavated 20 shovel tests (Greaves et al. 2004:81). The site was considered to have no research potential and was recommended as not eligible for listing on the NRHP or formal designation as a SAL.

Only a small portion of 41BX659 remained intact when it was first identified (McGraw and Hindes 1987:221). It is located north of Medina River. When CAR revisited the site in 2003 no material was recovered from shovel tests (Greaves et al. 2004:83). It appears that intact materials were removed by erosion. Further work was not recommended and the site was recommended as not eligible for listing as a NRHP or formal designation as a SAL.

Site 41BX830 will not be crossed by the trail but is just northeast of the proposed corridor. It is a multi-component site with a prehistoric and historical component (Adovasio and Green 2003:292). The historic component consists of a pre-1900 farm house and outhouse, along with artifacts. The prehistoric component was observed in an eroding cut bank. Site forms indicate the site is potentially eligible for listing as a NRHP and SAL.

41BX654 is located north of Medina River and was first identified in 1984 (McGraw and Hindes: 216). The site is located north of Medina River and it will not be impacted by the proposed trail. It was originally described as not eligible for SAL listing or NRHP nomination. CAR revisited the site in 2003 and only a few artifacts were recovered (Greaves et al. 2004). Erosion had impacted the site and it was recommended as not eligible for designation as a SAL or listing to the NRHP.

Site 41BX655 is also located northwest of Medina River. Reportedly, 70\% of the site was intact (McGraw and Hindes 1987:217) and consisted of lithic debitage and burned rock. During the revisit by CAR in 2003, the site had been heavily impacted by power line installation (Greaves et al. 2004:73). Further work was not recommended at the site, due to the low frequency of artifacts and recent disturbances. The site was recommended as not eligible for listing as a SAL or nomination to the NRHP.

41BX832 is located north of the Medina River and will not be impacted by the proposed trail. The site was identified by TAMU in 1989 and is listed as a SAL (THC 2007). The site was associated with a buried paleosol observed in an arroyo cut at $5.25 \mathrm{mbs}$ and consisted of lithic flakes. The site could not be relocated by CAR in 2003 therefore its NRHP eligibility could not be determined (Greaves et al. 2004:87). 


\section{Chapter 3: Field and Laboratory Methods}

CAR conducted a 100 percent pedestrian survey and shovel testing along the Phase II portion of the proposed trail corridor. This survey was conducted according to THC guidelines as a linear survey with a corridor $<30$ meters wide (16 shovel tests per mile). The survey corridor was subjected to one transect that ran along the proposed trail alignment. Due to the shallow impacts $(24 \mathrm{~cm})$ associated with the proposed Medina River Trail, only shovel testing was the only form of excavation implemented.

\section{Shovel Testing}

Shovel tests were excavated at 100 meter intervals, unless otherwise prevented. When positive shovel tests outside previously recorded sites were excavated, additional shovel tests were excavated within $10 \mathrm{~m}$ along the proposed alignment. Shovel tests were $30 \mathrm{~cm}$ in diameter and excavated to a maximum depth of $60 \mathrm{~cm}$ below ground surface, in 10$\mathrm{cm}$ levels. Soils were screened through 1/4-inch mesh. All artifacts were collected and observations were recorded on standardized forms. All shovel test locations were recorded with a GPS unit and plotted on an aerial field map. All artifacts recovered in shovel tests were returned to the CAR laboratory for processing, analysis and curation.

\section{Site Revisits}

Eight previously recorded sites are located along the proposed trail corridor (41BX531, 41BX533, 41BX537, 41BX538, 41BX545, 41BX546, and 41BX833, 41BX831). All of the sites were revisited and reassessed during the archaeological investigations. The previously recorded sites were relocated using aerial photographs and GPS units that contained the UTM coordinates of the sites (obtained from the Texas Archeological Sites Atlas). Once a site was relocated, crewmembers made written observations regarding the types of cultural materials noted on surface, the relative density of artifacts and temporal diagnostics. On sites with historic structures the condition and location of structures was documented (with GPS units) and each structure was photographed. Additional shovel tests (1 to 5) were excavated only in the portions where the previously recorded sites were intersected by the proposed trail alignment.
Artifacts that were not within site boundaries and that did not meet the criteria of a site were classified as isolated finds. In the Scope of Work prepared for THC, antiquities permit, we defined a site as: 1) locations with at least five artifacts within a $30 \mathrm{~m} 2$ area or; 2) a location containing a single cultural feature such as a hearth, either on surface or exposed in a shovel test or; 3) a location with a positive shovel test containing at least three artifacts within a given $10-\mathrm{cm}$ level or; 4) a location with a positive shovel test containing at least five total artifacts or; 5) two positive shovel tests located within $30 \mathrm{~m}$ of each other.

Site revisit forms for each revisited site were submitted to the Texas Archeological Research Laboratory (TARL) for submission to the Texas Archeological Sites Atlas.

\section{Laboratory Methods}

All cultural material collected during the survey was prepared in accordance with federal regulation 36 CFR part 79 , and in accordance with current guidelines of the Center for Archaeological Research. Artifacts were processed in the CAR laboratory where they were washed, air-dried, and stored in archival-quality bags. Artifacts were sorted into appropriate analytical categories. Acid-free labels were placed in all artifact bags. Each label displayed provenience information and a corresponding lot number laser printed or written in pencil.

Artifacts were separated by class and stored in acid-free boxes identified with standard labels. The data was entered into a Microsoft Access database. All artifacts are permanently curated at CAR.

Field notes, forms, and hard copies of photographs were placed in labeled archival folders. All field forms were completed in pencil. Documents and forms were printed on acid-free paper and any soiled forms were placed in archivalquality page protectors. A copy of the final report in Adobe Acrobat ${ }^{\circledR}$ file format and all digital material pertaining to the project, including photographs, were burned onto a CD and are permanently curated with the field notes and documents at the Center for Archaeological Research. 



\section{Chapter 4: Results of the Archaeological Investigations}

CAR conducted a 100 percent intensive pedestrian survey on the Phase II portion of the proposed Medina River Park. A total of 59 shovel tests were excavated during the archaeological investigations. Eight previously recorded sites that were intersected by the proposed trail corridor were revisited that included; 41BX546, 41BX545, 41BX533, 41BX531, 41BX537, 41BX538, 41BX833, and 41BX831. During the shovel testing of sites 41BX545 and 41BX833 no cultural material was recovered. Moreover, 41BX831 (the Richard Beene site) was revisited but only one shovel test was excavated. The site has been heavily modified by earth moving activities (Thoms et al. 1996). Portions of the trail traversed areas that ranged from heavily vegetated to plowed areas that were sparsely vegetated.

\section{Off-site Shovel Tests}

Thirty shovel tests were excavated along the portions of the proposed trail that fell outside of archaeological site boundaries. Only one shovel test (ST 6) was positive and contained a piece of flow blue ceramic. Two additional shovel tests were excavated ten meters to the east (ST 60) and west (ST 59) of the positive shovel test and no additional material was recovered. The material from ST 6 was recorded as an isolated find.

\section{Site Revisit}

Twenty-nine shovel tests were excavated within the boundaries of the eight previously recorded sites. Only nine of these shovel tests were positive for cultural material (Table 4-1). This section discusses the revisit of each site and the results. Three of the sites are designated as SAL's (41BX538, 41BX833 and 41BX831). No cultural material was encountered at 41BX833 or 41BX831.

\section{BX546}

Site 41BX546 is located along the southern terrace of the Medina River (McGraw and Hindes 1987:199). During the original recording of the site lithic debitage, core fragments, burned rock and mussel shell fragments were observed on the surface (McGraw and Hindes 1987:199). The CAR field crew revisited the southern portion of the site that will be crossed by the proposed trail. The southern portion of the site was located in a fallow agricultural field (Figure 4-1) traversed by a narrow two-tract dirt road, while the northern portion is covered in live oak and shrubs. Seven shovel tests were
Table 4-1. Shovel Tests Excavated on Previously Recorded Sites

\begin{tabular}{|c|c|c|}
\hline Site & Shovel Test \# & Results \\
\hline 41BX538 & 40 & negative \\
\hline 41BX538 & 41 & positive \\
\hline 41BX538 & 42 & positive \\
\hline 41BX538 & 43 & positive \\
\hline 41BX538 & 44 & positive \\
\hline 41BX538 & 45 & positive \\
\hline $41 \mathrm{~B} \times 546$ & 1 & negative \\
\hline $41 B \times 546$ & 2 & negative \\
\hline $41 B \times 546$ & 3 & positive \\
\hline $41 B \times 546$ & 14 & negative \\
\hline 41BX546 & 15 & negative \\
\hline $41 B \times 546$ & 16 & negative \\
\hline $41 B \times 546$ & 17 & negative \\
\hline 41BX546 & 18 & negative \\
\hline $41 B \times 546$ & 19 & negative \\
\hline $41 B \times 545$ & 10 & negative \\
\hline 41BX545 & 11 & negative \\
\hline $41 B \times 545$ & 12 & negative \\
\hline $41 B \times 545$ & 13 & negative \\
\hline 41BX533 & 26 & negative \\
\hline 41BX533 & 27 & positive \\
\hline 41BX533 & 28 & positive \\
\hline 41BX533 & 29 & negative \\
\hline 41BX533 & 61 & negative \\
\hline 41BX531 & 38 & positive \\
\hline 41BX833 & 47 & negative \\
\hline 41BX833 & 55 & negative \\
\hline 41BX833 & 56 & negative \\
\hline 41BX831 & 48 & negative \\
\hline
\end{tabular}

excavated within the site boundaries (Figure 4-2). One piece of debitage and burned rock was observed on the surface, just west of the site boundary, and two additional shovel tests were excavated (ST 18 and 19). With the exception of Shovel Test 3 that contained one piece of white earthen ware in Level 1, all other shovel tests were void of cultural material. Shovel tests revealed the soils on the site consisted of a loose pale brown (10YR 6/3) silt matrix. Although no prehistoric material was observed in the shovel tests, the surface distribution suggests that the site boundaries should be extended to the west to include the surface material. It had 


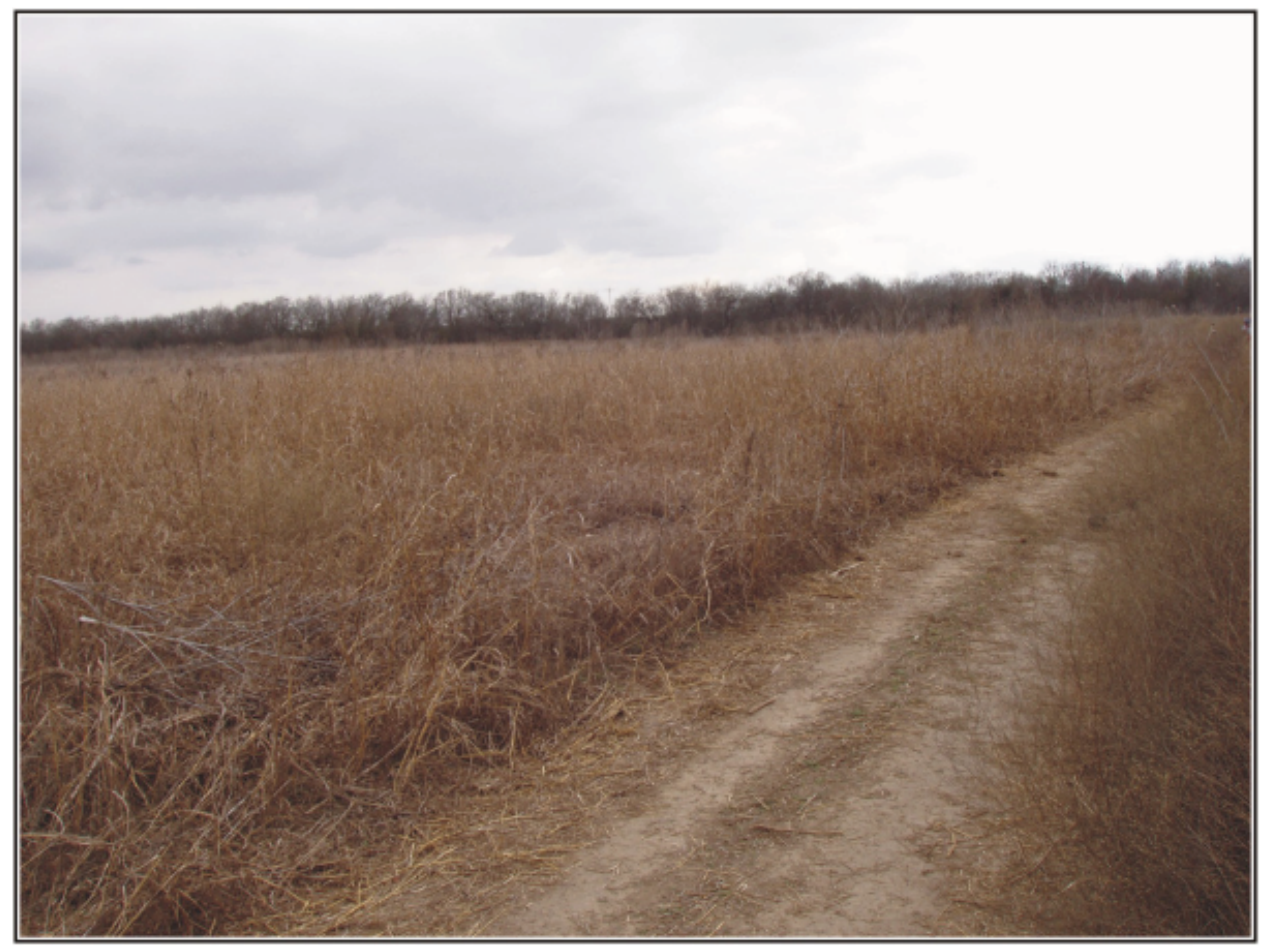

Figure 4-1. The southern portion of 41BX546 located in a field.

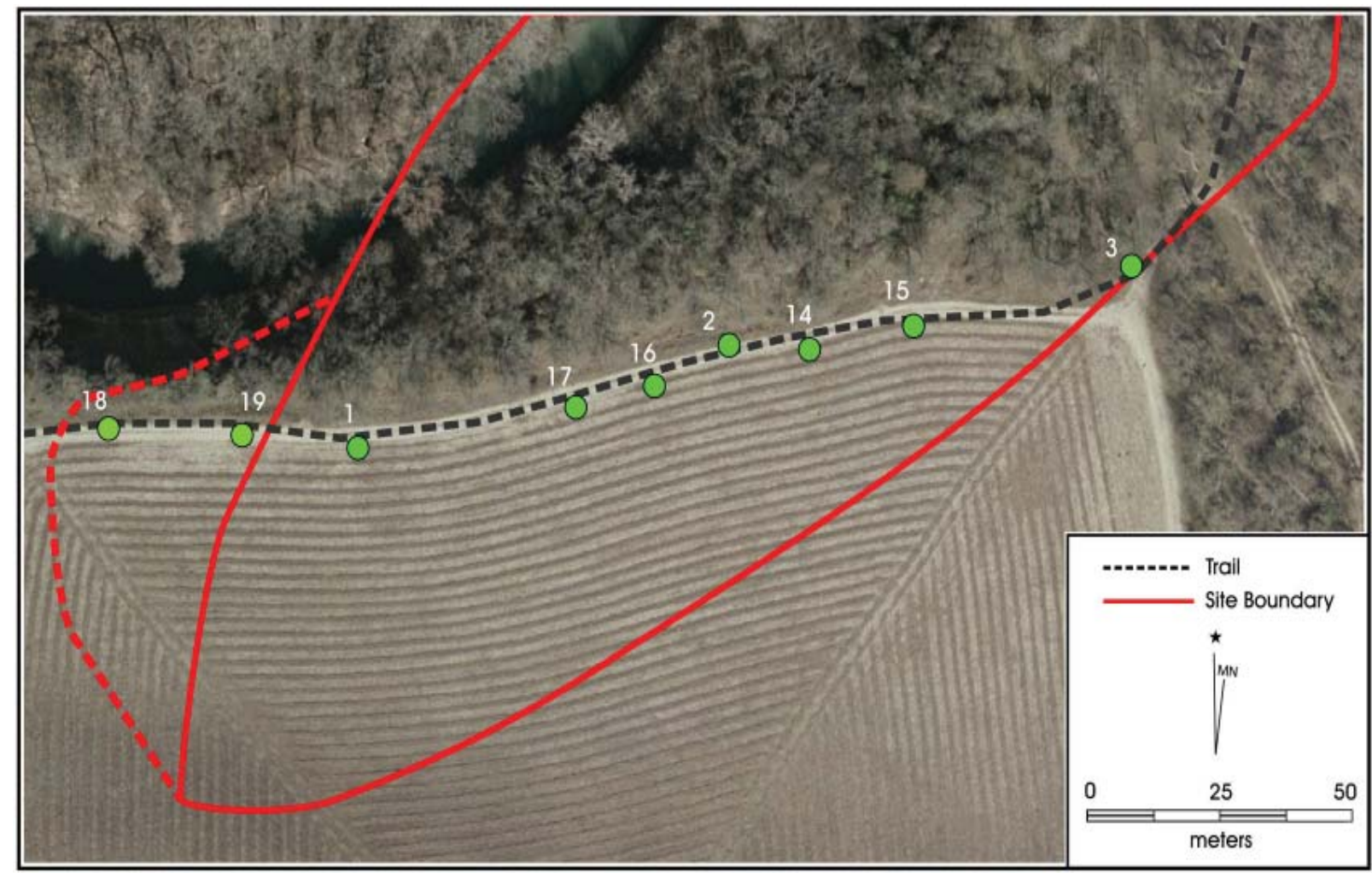

Figure 4-2. Shovel test locations on 41BX546 and extended site boundary (dashed line). 
been suggested that buried deposits may be present in the area (McGraw and Hindes 1987:199) but the current shovel testing indicates no evidence of buried deposits and further work is not recommended. The portion of the site that was investigated is not recommended as eligible for listing as a NRHP or SAL.

\section{BX545}

41BX545 is located just south of the Medina River. During the initial recording of the site, it was reported as consisting of a scatter of debitage and burned rock (McGraw and Hindes 1987). It was revisited during the current investigations. The southern half of the site was located in a fallow agricultural field while the northern portion was vegetated by oak trees, mesquite, and prickly pear (Figures 4-3 and 4-4). A fence line and two tract dirt road intersected the site.

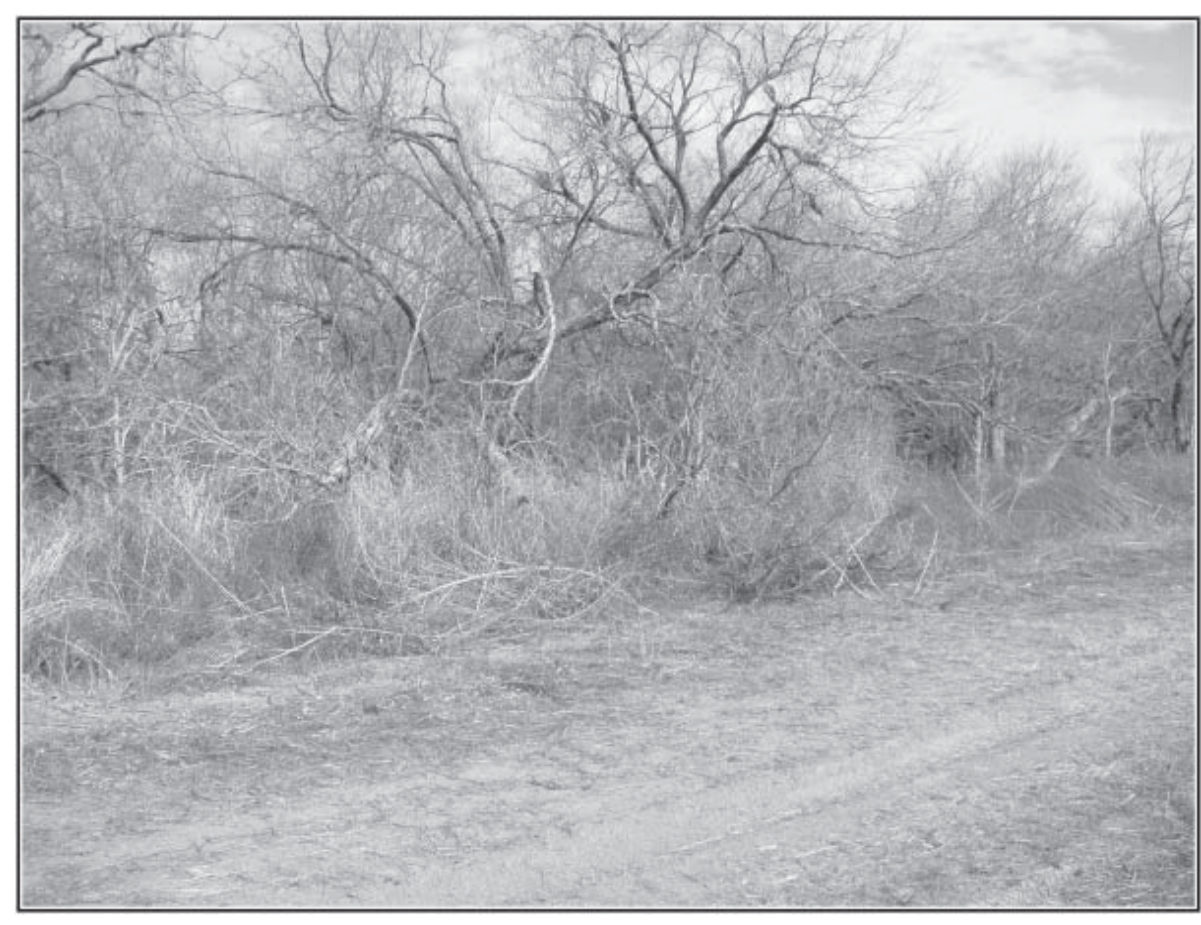

Figure 4-4. The southern portion of $41 B X 545$ located in a field.

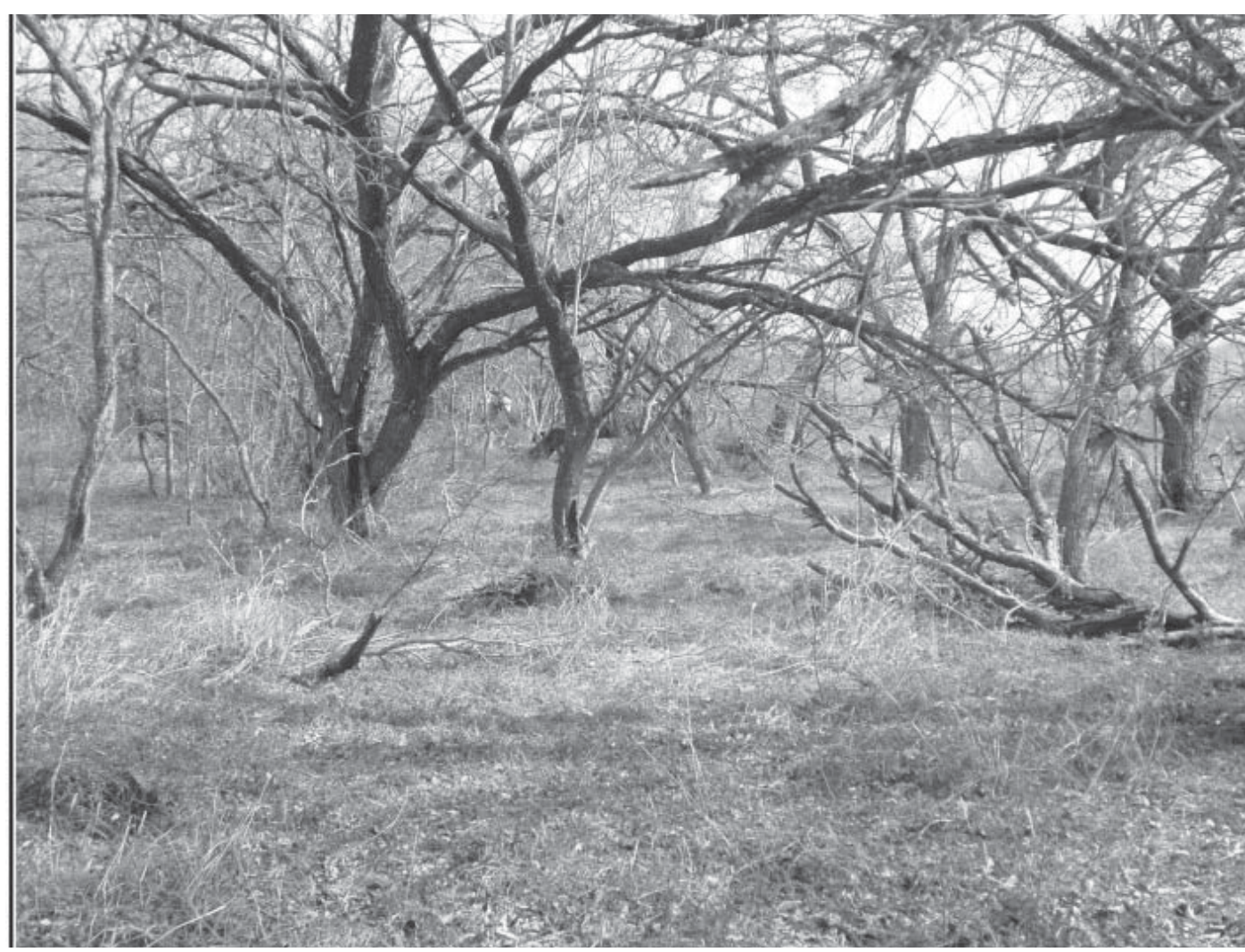

No cultural material was observed on the surface. Four shovel tests were excavated within the site boundaries (Figure 4-5) and all were negative of cultural material. Soils on the site consisted of a compact dark grayish brown silt matrix. Further work is not recommended at the site. The portion of the site that was investigated is not recommended as eligible for listing on the NRHP or formal designation as a SAL.

Figure 4-3. The vegetated northern portion of 41BX545. 


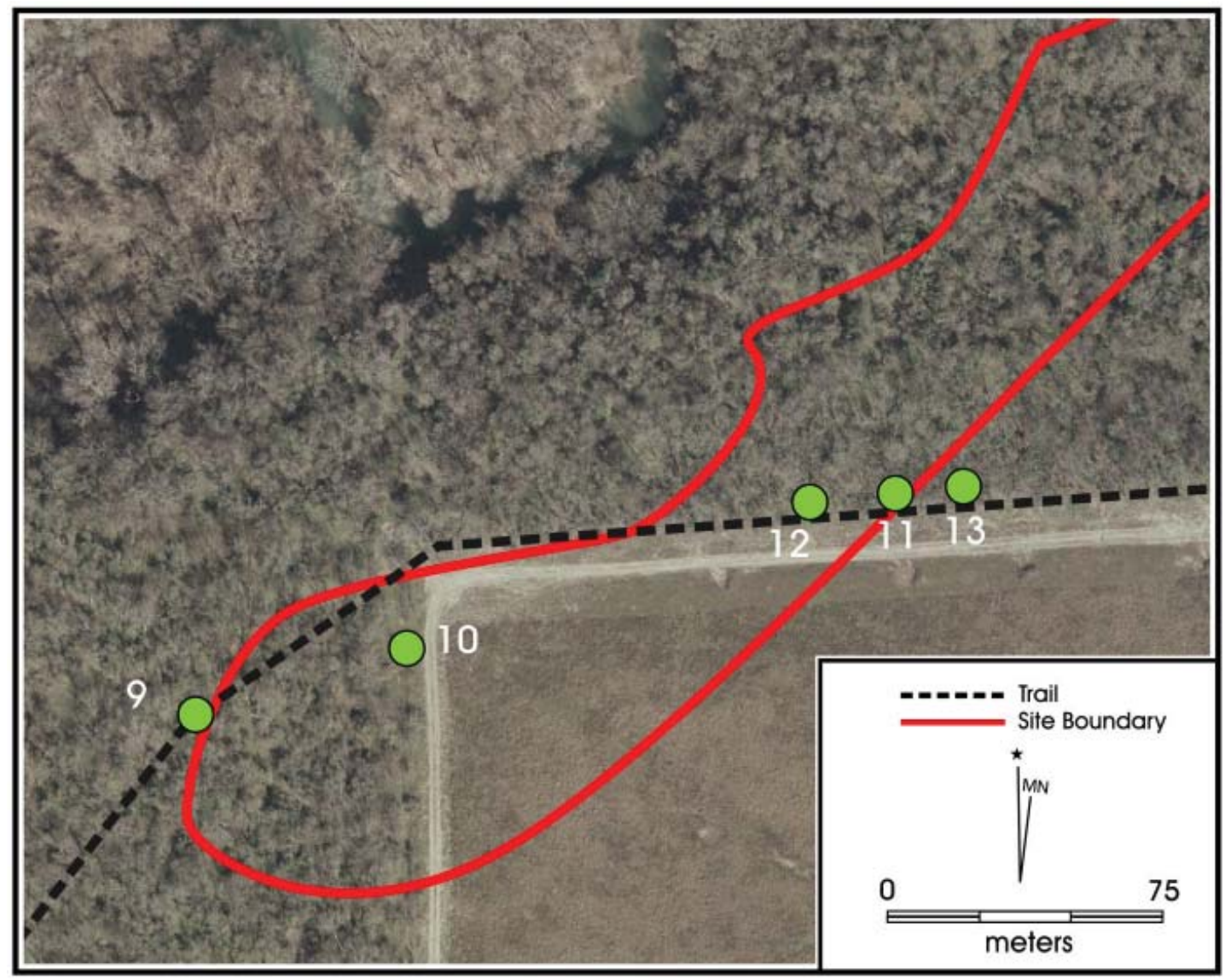

Figure 4-5. Shovel test locations on 41BX545.

\section{BX533}

The initial recording of the site indicated lithic debitage, an Early Triangular biface, burned rock and mussel shell eroding out of gullies along the slope of the area (McGraw and Hindes 1987:178). The site is bound by the Medina River to the north and by an arroyo complex to the south. Prickly pear and Spanish dagger species were observed in the site area. The CAR field crew revisited the site and observed material on the surface that included burned rock, debitage and mussel shell fragments. The site is disturbed by gully erosion (Figures 4-6 and 4-7). Three shovel tests were excavated on the site and two of them were positive for cultural material (Table 4-2). Cultural material recovered from the two shovel tests included white earthen ware (Level 2), burned rock (Level 2), mussel shell fragments (Level 4) and debitage (Level 2). Soils revealed in shovel tests consisted of a loose dark grayish brown $(10$ YR 4/2) silt. Due to the heavy erosion occurring at the site, further work is not recommended at the site. Furthermore, the portion of the site that was investigated is not recommended as eligible for listing as a NRHP or formal designation as a SAL.

\section{BX531}

Site 41BX531 is located south of the Medina River on a high terrace. It was recorded as consisting of a fallen historic structure and a prehistoric component. No further work was recommended on the historic component (Adovasio and Green 2003). Reportedly, the prehistoric component contained lithic debitage, mussel shell, burned rock and a Late Prehistoric biface. According to the Texas Archeological Sites Atlas, mitigation was recommended at this site. CAR revisited the portion of the site that intersected the proposed trail corridor (Figure 4-8). This portion of the site was located on a high terrace bound by steep drainages to the east and north.

A temporary structure constructed of wood was erected on this portion of the site (Figure 4-9) and associated with modern camping supplies such as sleeping bags and tarps. The remnants of a modern campfire were located just adjacent to the temporary structure. The structure served as a sweat lodge for the local group of American Indians in Texas at the Spanish Colonial Missions (AIT-SCM) in 2007 (AIT-SCM 2008). Due to the modern use of the area and the drainages, to the east and to the north, only one shovel test (ST 38) was 


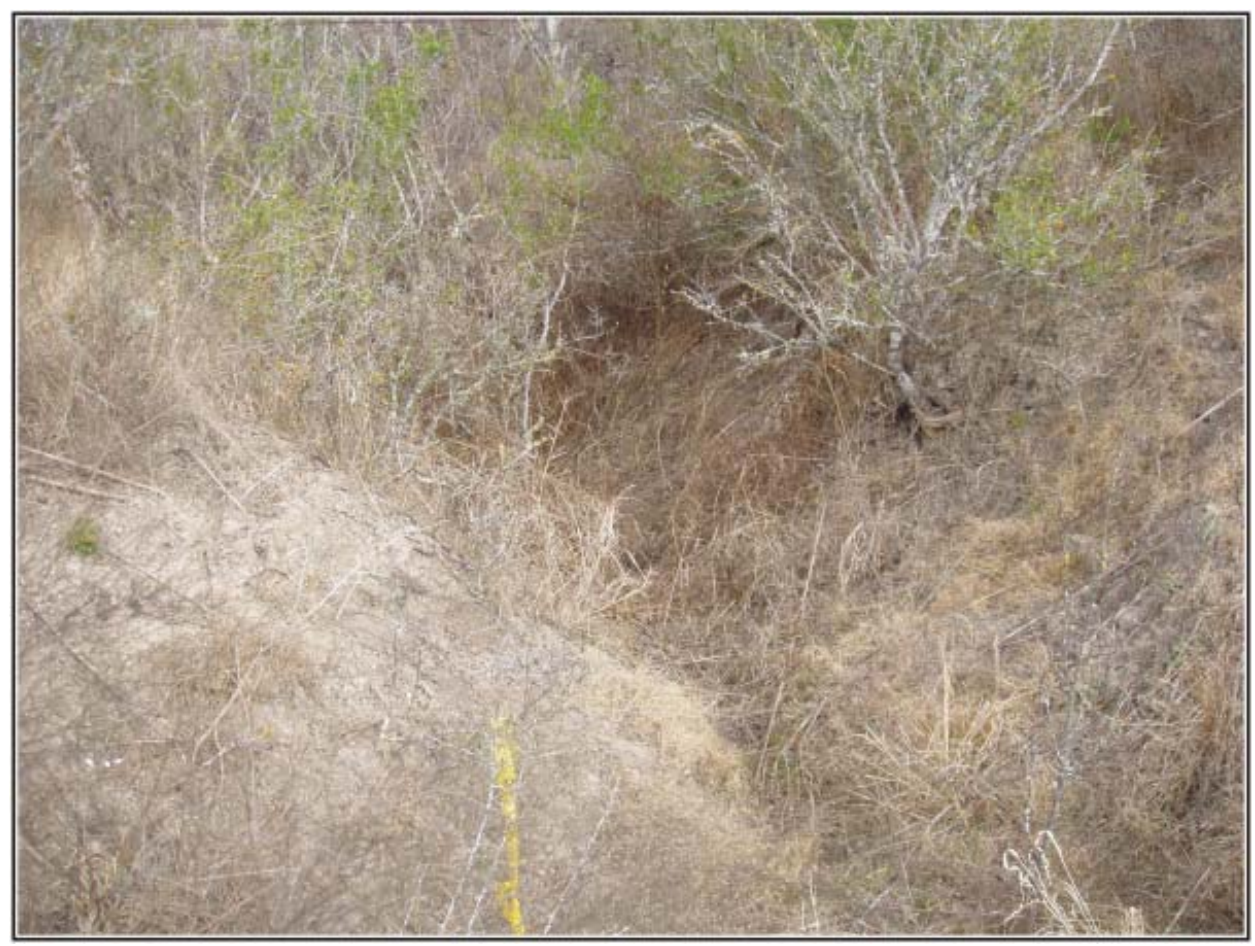

Figure 4-6. Erosion on 41BX533.

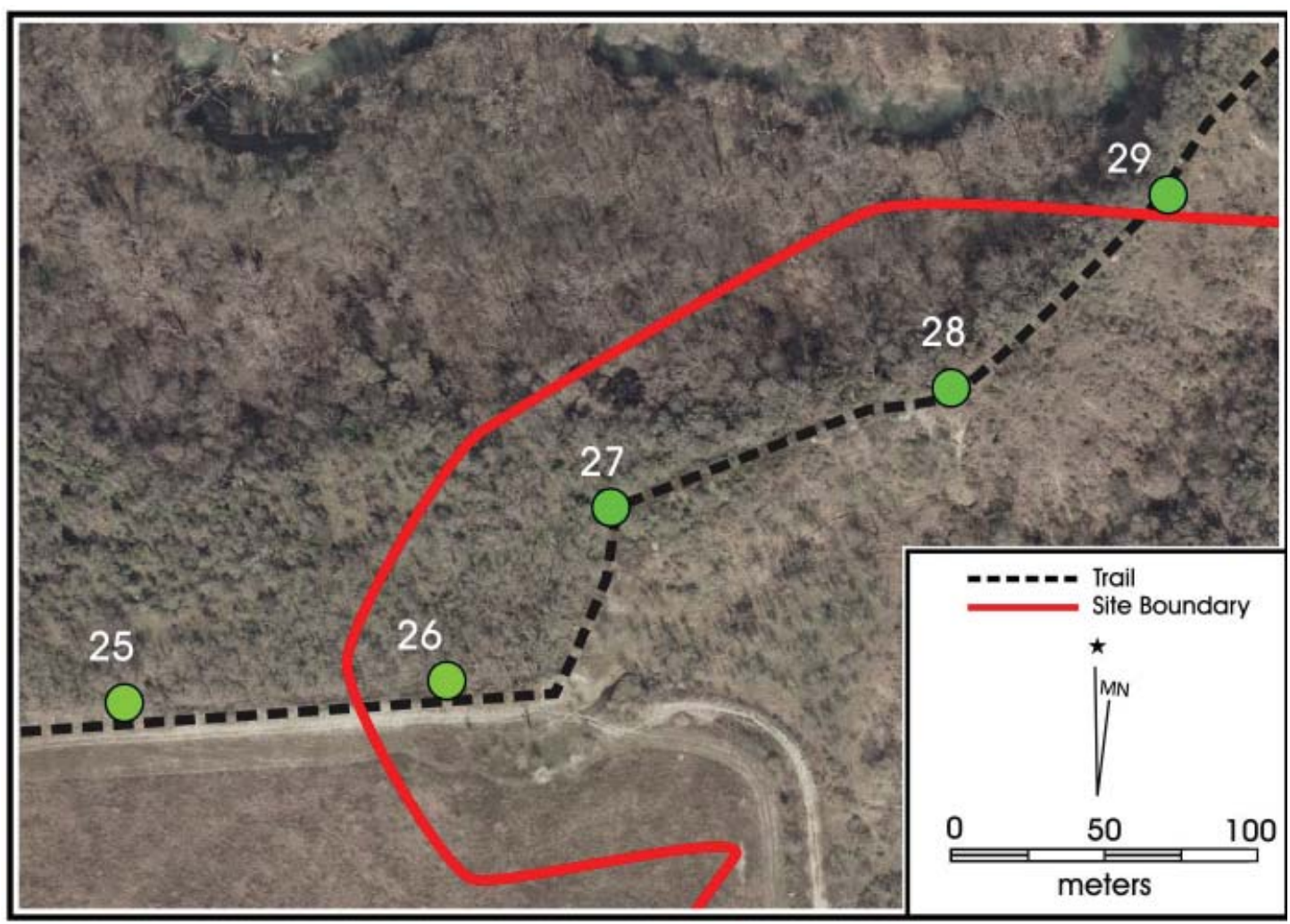

Figure 4-7. Shovel test locations on 41BX533. 
Table 4-2. Positive Shovel Tests Excavated at 41BX531 and 41BX533

\begin{tabular}{|c|c|c|c|c|c|c|c|}
\hline Site & Shovel Test & Level & Burned Rock & Ceramics & Debitage & Mussel Shell & Total \\
\hline \multirow{4}{*}{41 BX533 } & 27 & 2 & 1 & 2 & & 0 & 3 \\
\cline { 2 - 8 } & 28 & 4 & 0 & 0 & 0 & 1 & 1 \\
\hline $\begin{array}{c}\text { 41BX533 } \\
\text { Total }\end{array}$ & & 2 & 0 & 0 & 1 & 0 & 1 \\
\hline 41BX531 & 38 & 1 & 1 & 2 & 1 & 1 & 5 \\
\hline $\begin{array}{c}\text { 41BX531 } \\
\text { Total }\end{array}$ & & & 0 & 0 & 1 & 0 & 1 \\
\hline
\end{tabular}

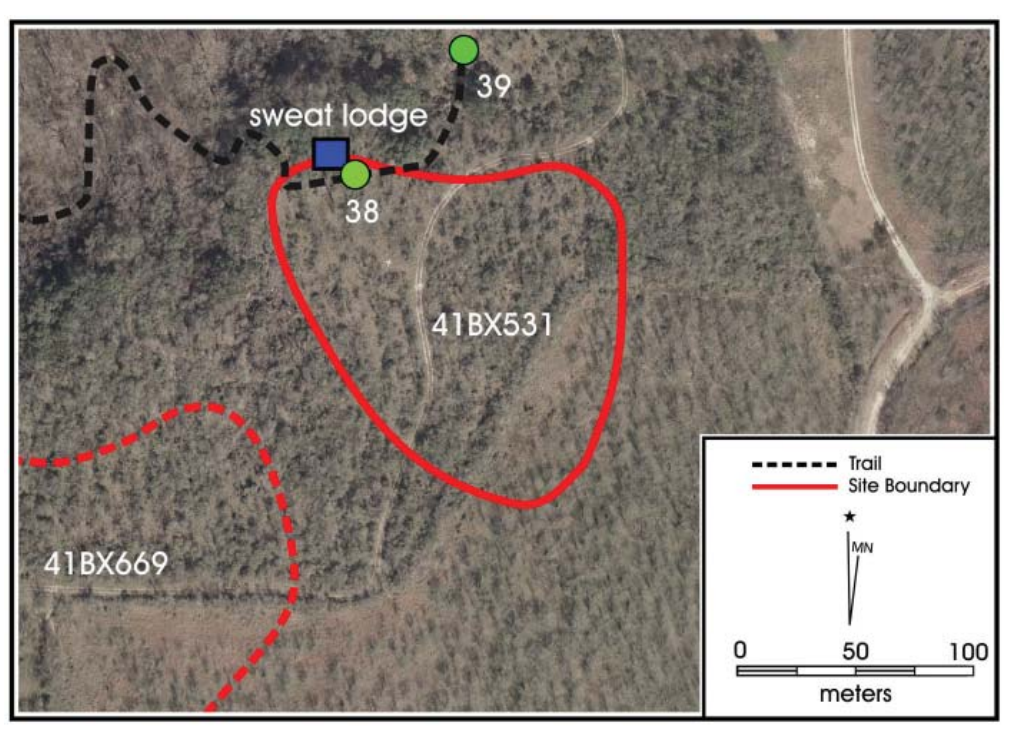

Figure 4-8. Shovel test locations on 41BX531.

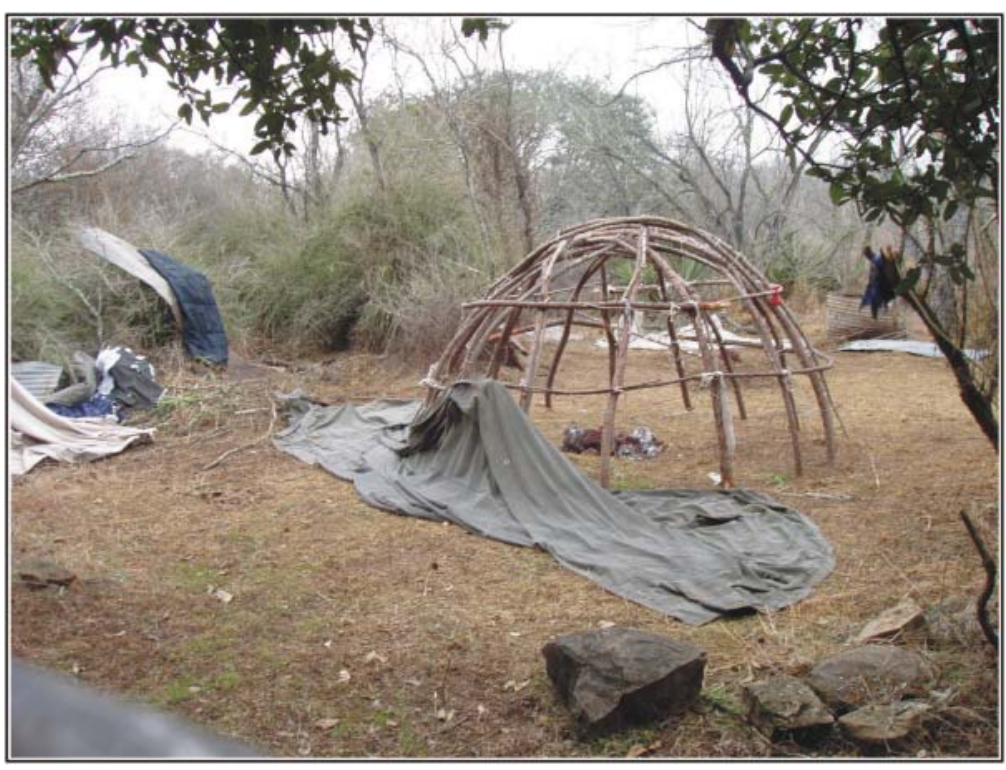

Figure 4-9. Sweat lodge erected within the boundary of 41BX531. excavated on the site. The shovel test contained one piece of debitage in Level 1 (see Table 4-2). The soil revealed in the shovel test was a loose yellowish brown silty matrix. The portion of the site that was investigated is recommended as not eligible for listing on the NRHP or formal designation as a SAL.

\section{BX538 (Presnall/Watson Place)}

41BX538 is also known as the Presnall/Watson Place and was investigated by TAMU and SMU in 1989 as part of the Applewhite Reservoir project (Adovasio and Green 2003). Testing of the historic component of the site was performed by SMU and TAMU (Adovasio and Green 2003). In 1989 SMU excavated 20 test units (50 cm x 50 cm). In 1991, a total of 146 test units were excavated by TAMU. Final HABS drawings of the structures were completed by TAMU. The site was deemed NRHP eligible under Criteria A and D (Adovasio and Green 2003:102). The prehistoric component of this site was given a separate trinomial (41BX537) but for the current study prehistoric materials were assigned to 41BX538.

Upon CAR's revisit of the site, six shovel tests were excavated within the site boundaries (Figure 4-10). The majority of the material recovered from the shovel tests consisted of debitage (Table 4-3) and mussel shell fragments. One piece of undecorated white earthen ware also was recovered. The prehistoric material was recovered from the southern portion of the site, while the historic ceramic sherd was located in the northern portion of the site. The shovel tests (41-44) that contained prehistoric material revealed a loose pale brown sand matrix. A small drainage runs just north of Shovel Tests 41-43. 


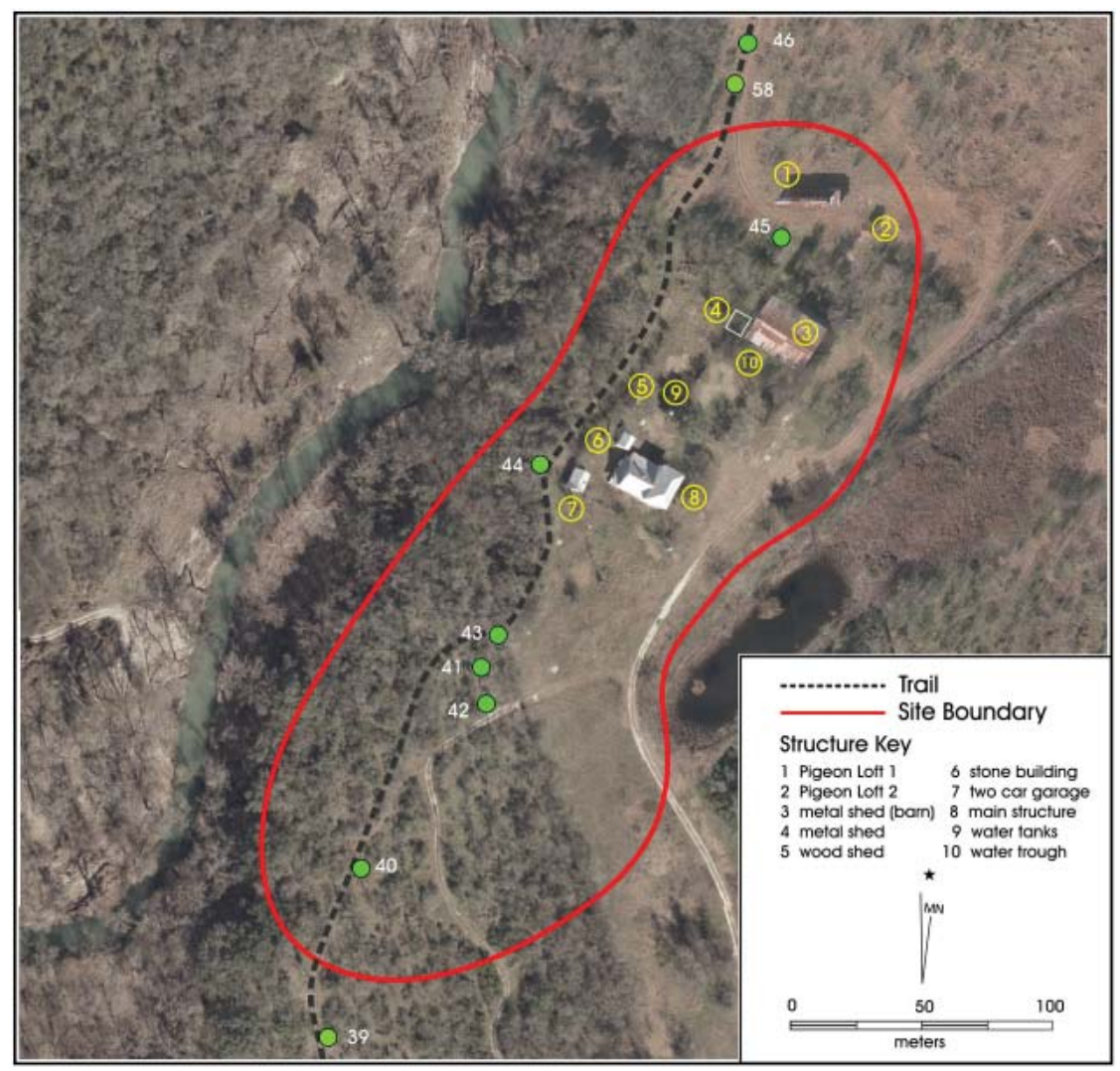

Figure 4-10. Shovel test locations on 41BX538 and outbuildings.
Seven structures were recorded by TAMU in 1991 (Advasio and Green 2003). During the current revisit, seven outbuildings and the main structure were recorded with a GPS unit (see Figure 4-10). Surveyors did not enter any of the buildings. Several of the buildings were boarded up. The main house (Figure 4-11) has been documented thoroughly in the past (Advasio and Green 2003). Outbuildings 1 and 2 are not part of the original homestead layout, rather these two pigeon lofts (Figure 4-12 and 4-13) were originally part of the 41BX681 site and relocated to 41BX538 (Greaves et al. 2004:109). Outbuilding 3 is a barn that was also documented by TAMU (Figure 4-14). Two building phases were noted for the barn by TAMU.

Outbuilding 4 is a metal shed also documented during previous investigations (Figure 4-15). Outbuilding 5, 6 and 7 were also documented by TAMU. Outbuilding 5 is a wooden shed (Figure 4-16) and Outbuilding 6 is a small stone structure (Figure 4-17). Outbuilding 7 had been described as a two car garage (Figure 4-18). A water trough made of cement is located between the large barn and the metal shed (Figure 4-19). A cypress water tank is located just north of the main house (Figure 4-20).

\begin{tabular}{|c|c|c|c|c|c|c|c|}
\hline Shovel Test & Level & Bone & Burned Rock & Ceramics & Debitage & Mussel Shell & Total \\
\hline \multirow{3}{*}{41} & 1 & 0 & 0 & 0 & 1 & 0 & 1 \\
\hline & 5 & 0 & 0 & 0 & 0 & 1 & 1 \\
\hline & 6 & 0 & 0 & 0 & 0 & 1 & 1 \\
\hline 41 Total & & 0 & 0 & 0 & 1 & 2 & 3 \\
\hline \multirow{5}{*}{42} & 1 & 0 & 0 & 0 & 1 & 0 & 1 \\
\hline & 2 & 0 & 1 & 0 & 0 & 1 & 2 \\
\hline & 4 & 0 & 0 & 0 & 0 & 1 & 1 \\
\hline & 5 & 1 & 0 & 0 & 0 & 0 & 1 \\
\hline & 6 & 0 & 0 & 0 & 0 & 1 & 1 \\
\hline 42 Total & & 1 & 1 & 0 & 1 & 3 & 6 \\
\hline \multirow{4}{*}{43} & 1 & 0 & 1 & 0 & 2 & & 3 \\
\hline & 2 & 0 & 0 & 0 & 1 & 1 & 2 \\
\hline & 4 & 0 & 0 & 0 & 1 & 1 & 2 \\
\hline & 6 & 0 & 0 & 0 & 1 & 1 & 2 \\
\hline 43 Total & & 0 & 1 & 0 & 5 & 3 & 9 \\
\hline \multirow{3}{*}{44} & 2 & 0 & & & & 1 & 1 \\
\hline & 3 & 0 & & & 1 & 1 & 2 \\
\hline & 4 & 0 & & & & 1 & 1 \\
\hline 44 Total & & 0 & & & 1 & 3 & 4 \\
\hline 45 & 2 & 0 & 0 & 1 & 0 & 0 & 1 \\
\hline 45 Total & & 0 & 0 & 1 & 0 & 0 & 1 \\
\hline Total & & 1 & 2 & 1 & 8 & 11 & 23 \\
\hline
\end{tabular}

Only one structure, the tractor shed, mapped by TAMU was not documented by the CAR crew. Instead of the tractor shed, the smaller of the pigeon coops (Outbuilding 2) was in this area where it had mapped by TAMU. It is recommended that the portion of the site that was investigated does not contribute to the SAL eligibility of the site. The site was nominated for NRPH listing under criteria $A$ and D (Advasio and Green 2003:199) but it is unclear whether it is currently listed. No signs of vandalism were noted on any of the structures present on 41BX538. However, occasional monitoring of the site may be required as the structures are visible from the trail and pedestrians may attempt to enter the structures. 


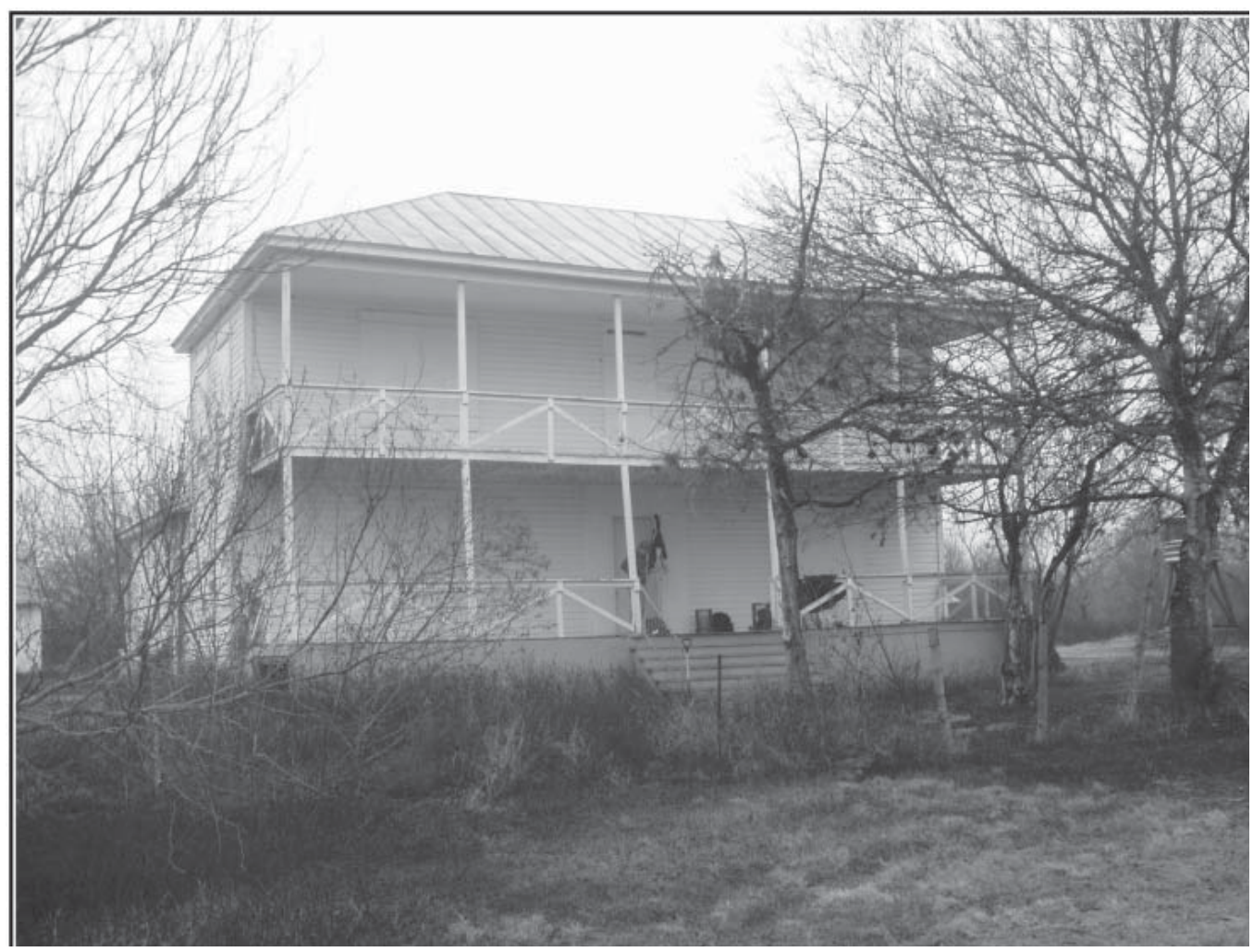

Figure 4-11. Main structure at 41BX538.

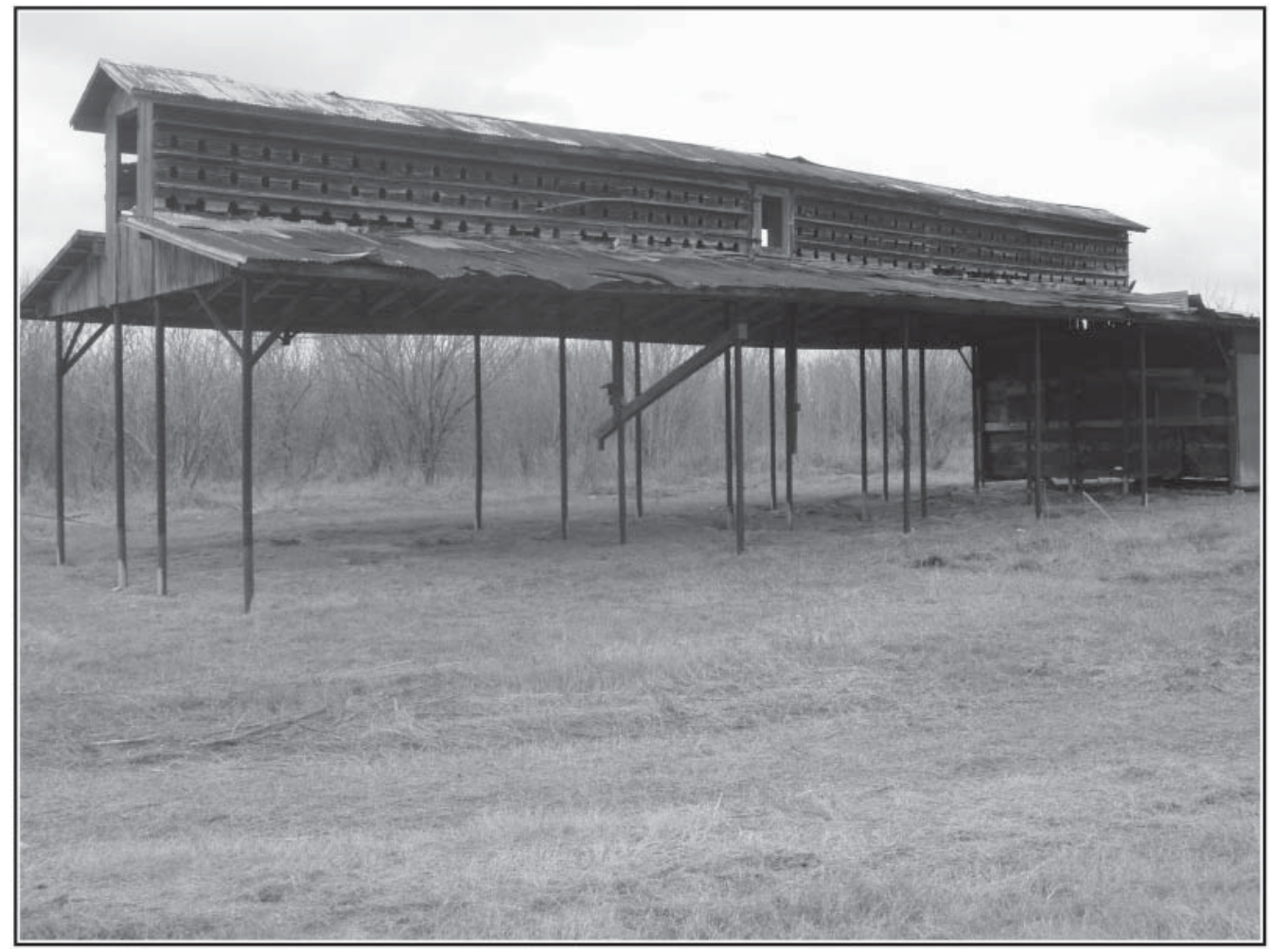

Figure 4-12. Pigeon coop 1 (Outbuilding 1) moved from 41BX681 to 41BX538. 


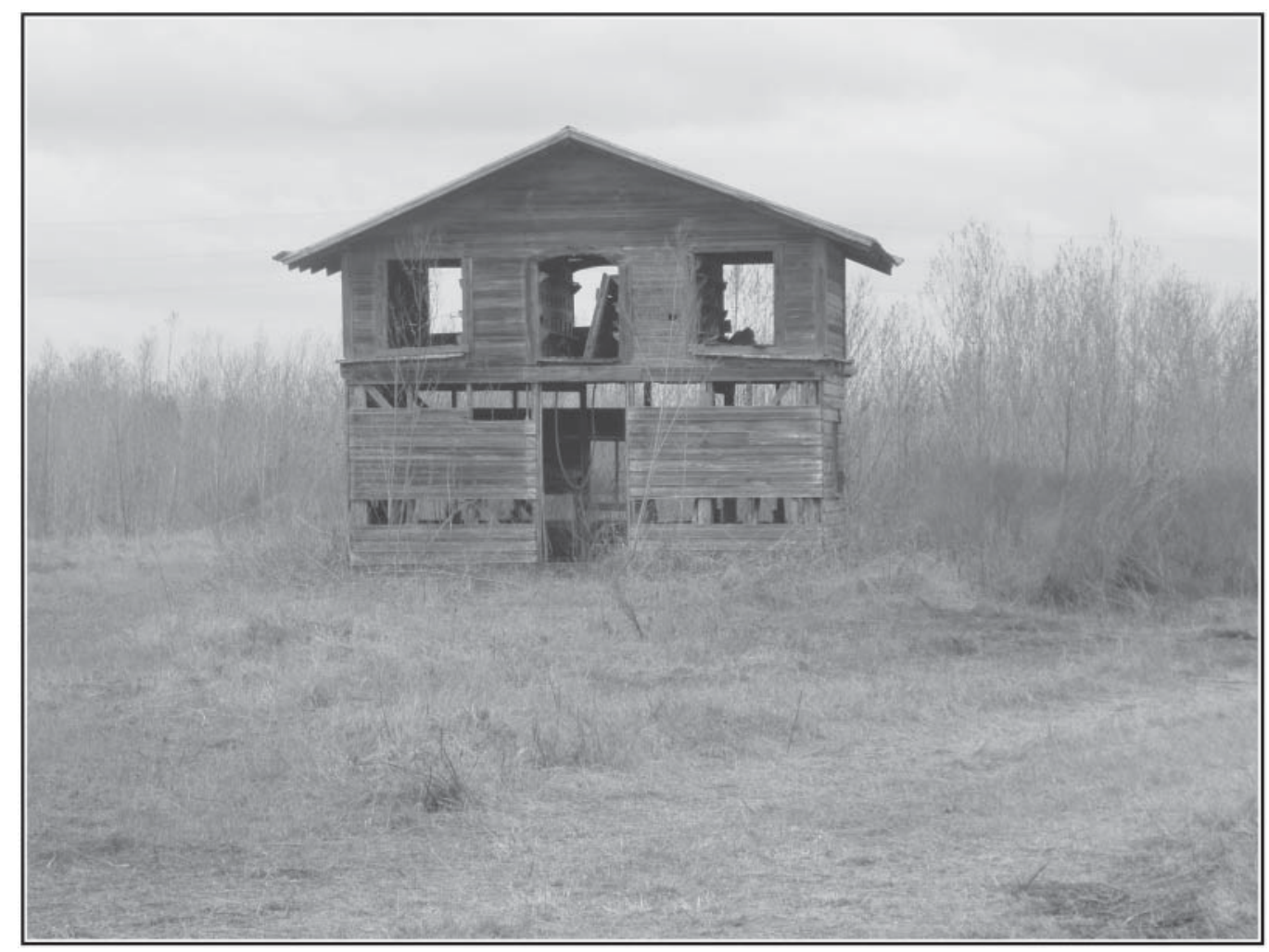

Figure 4-13. Pigeon coop 2 (Outbuilding 2) moved from 41BX681 to 41BX538.

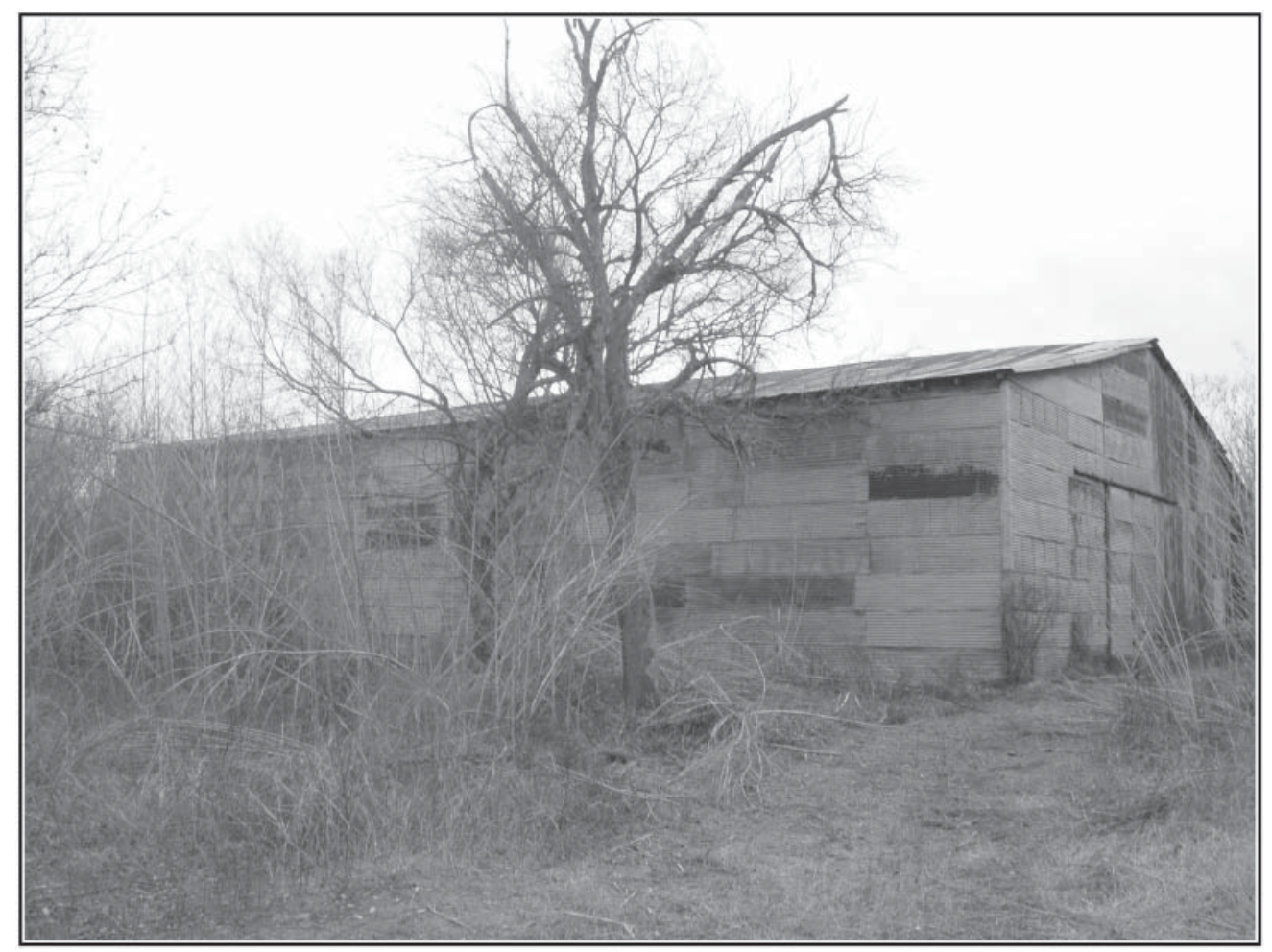

Figure 4-14. Metal barn (Outbuilding 3) on 41BX538. 


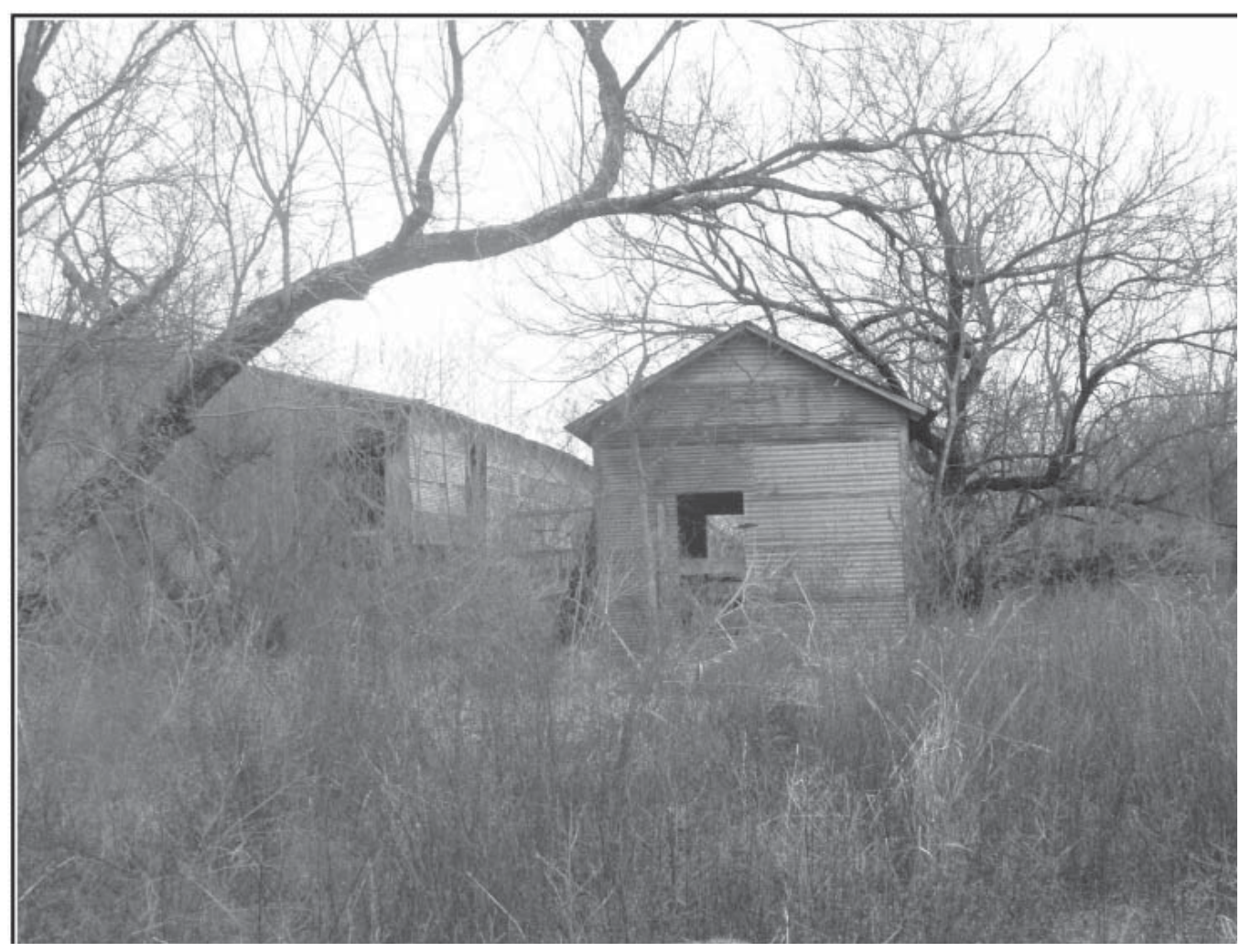

Figure 4-15. Metal shed (Outbuilding 4) adjacent to metal barn on 41BX538.

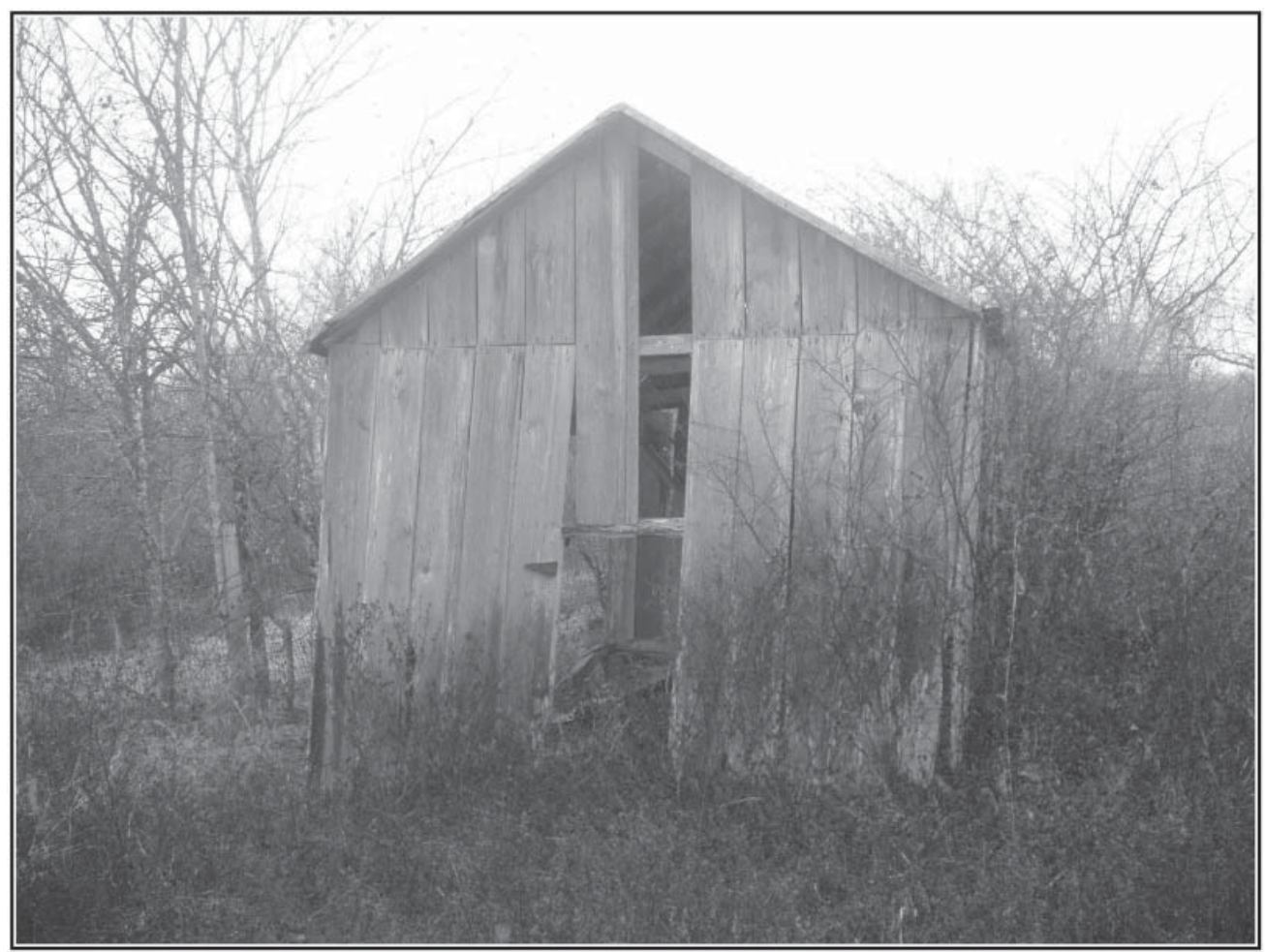

Figure 4-16. Wooden shed (Outbuilding 5) on 41BX538. 


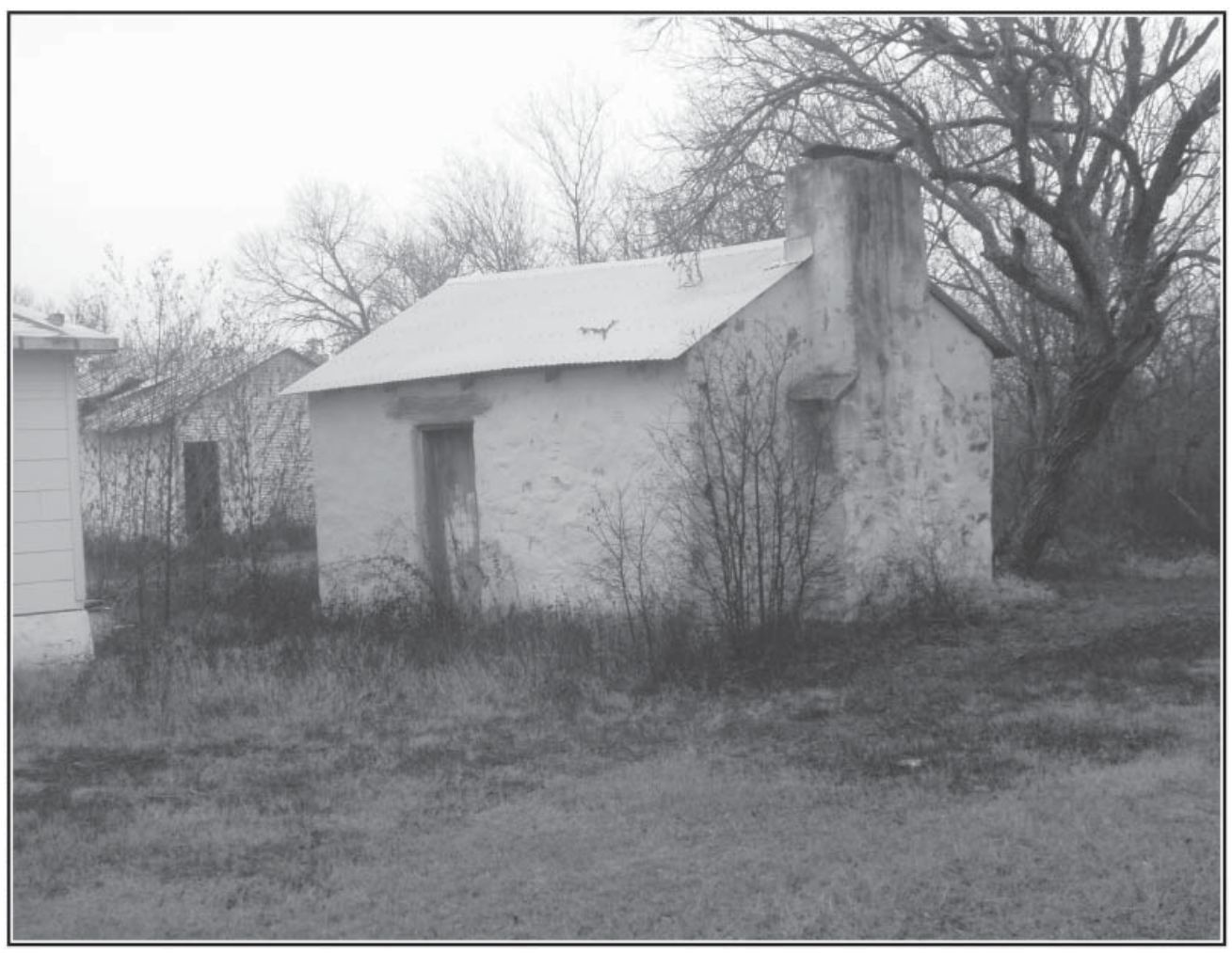

Figure 4-17. Stone building (Outbuilding 6) on 41BX538.

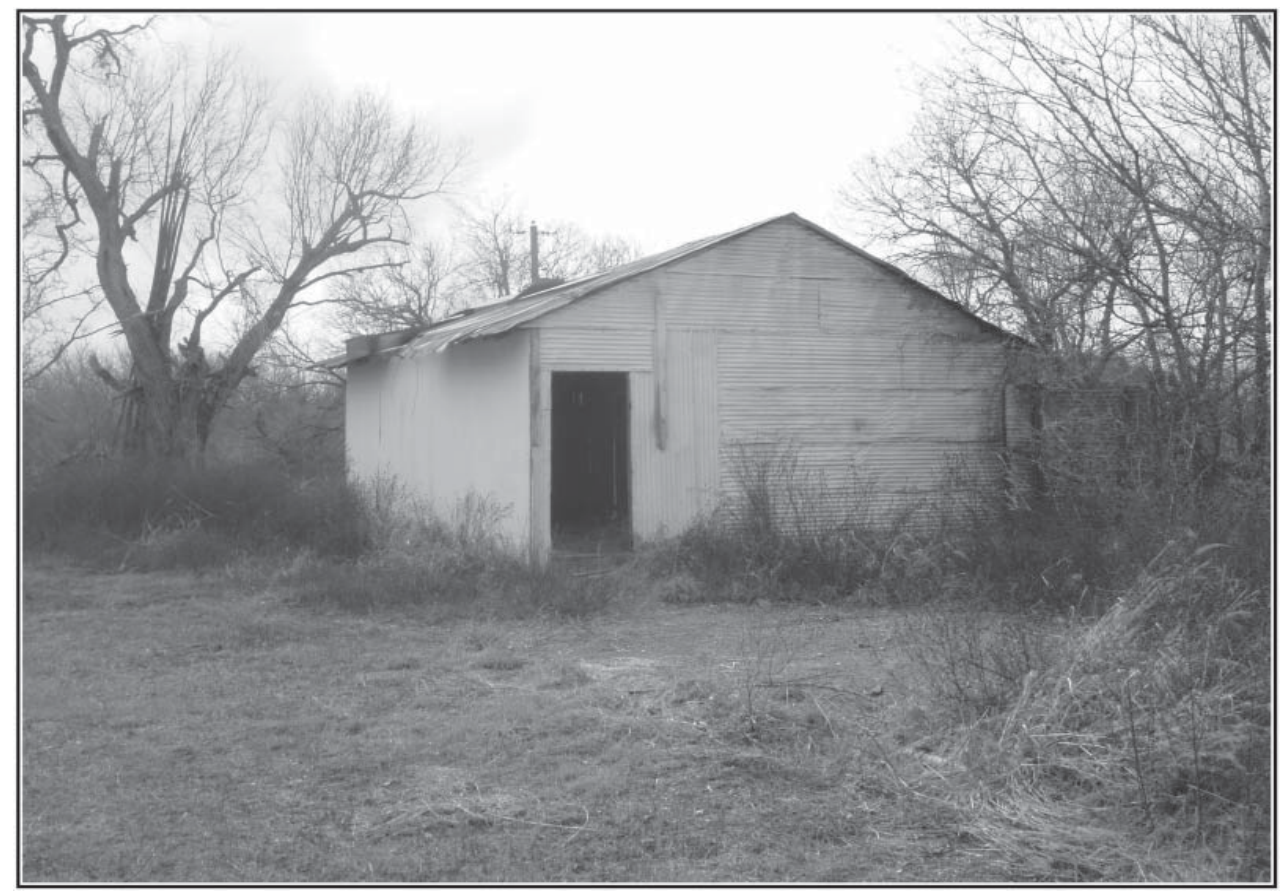

Figure 4-18. Two car garage (Outbuilding 7) on 41BX538. 


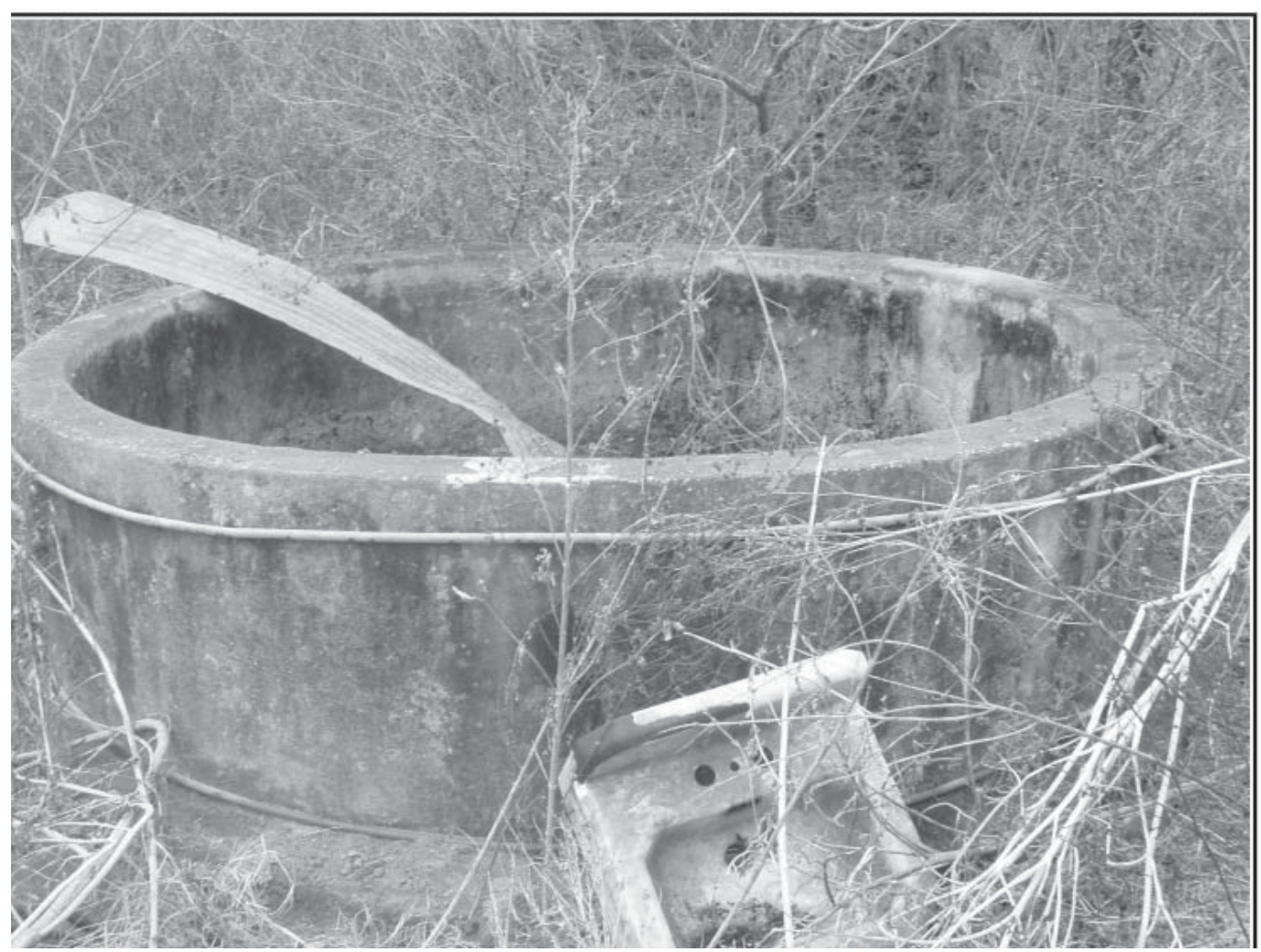

Figure 4-19. Water trough on 41BX538.

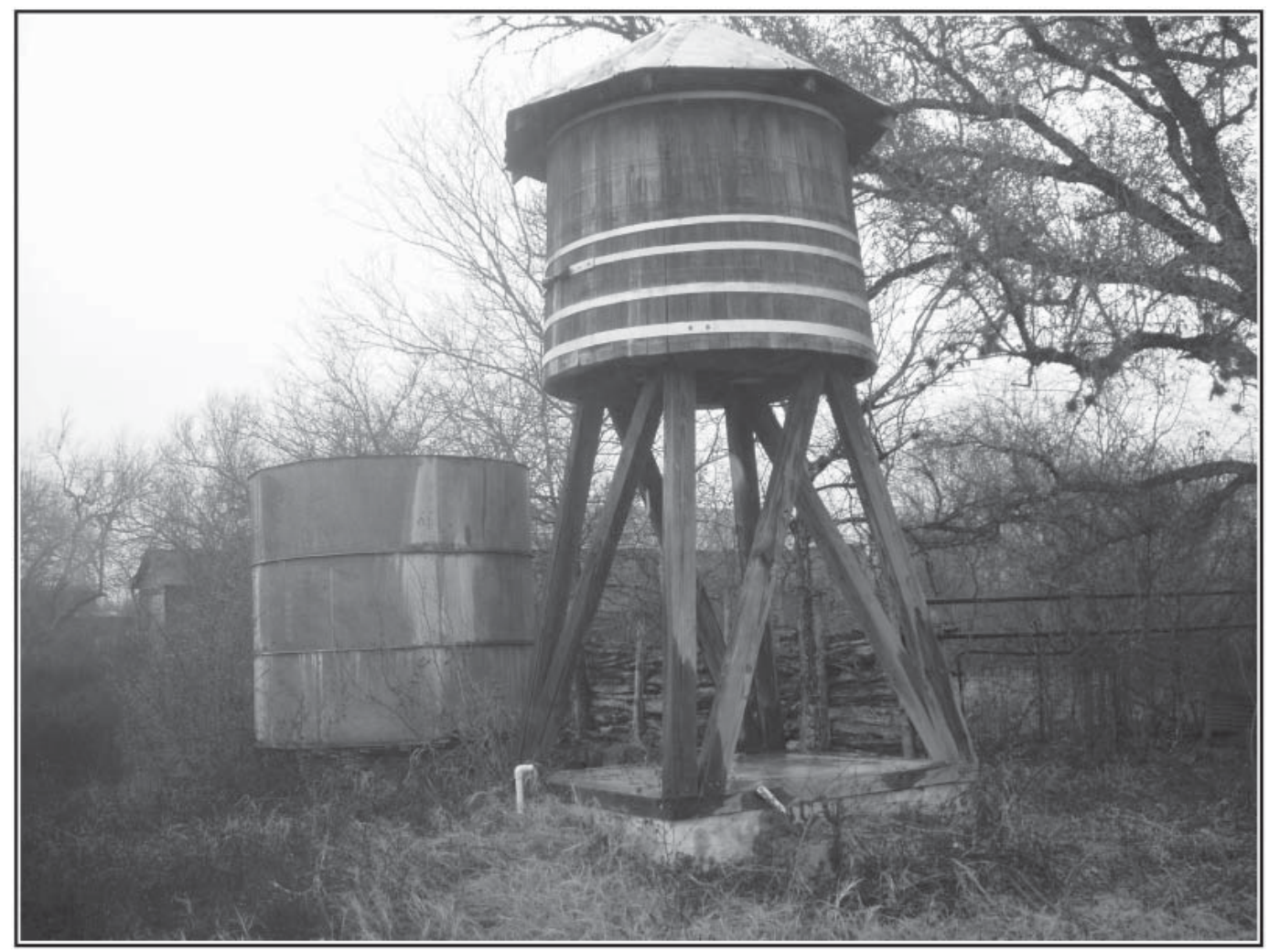

Figure 4-20. Water tank on 41BX538. 


\section{BX537}

41BX537 is the prehistoric component of site 41BX538. During SMU investigations in 1989, the site consisted of a Late Archaic and Late Prehistoric component. The Texas Archeological Sites Atlas shows this prehistoric component occurring on the north side of 41BX538. Further work on the site was not recommended due to the lack of intact prehistoric features and impacts caused by the site's historic component. The revisit of 41BX538 encountered prehistoric material in the southern portion of the site and it is recommended that the prehistoric component in this area of the site does not warrant nomination to the NRHP for formal designation as a SAL.

\section{BX833}

The SAL form for 41BX833 describes the site as a prehistoric camp and historic chimney (THC 2008). Three shovel tests were excavated on the portion of the site where the trail corridor is proposed to cross. All three shovel tests were

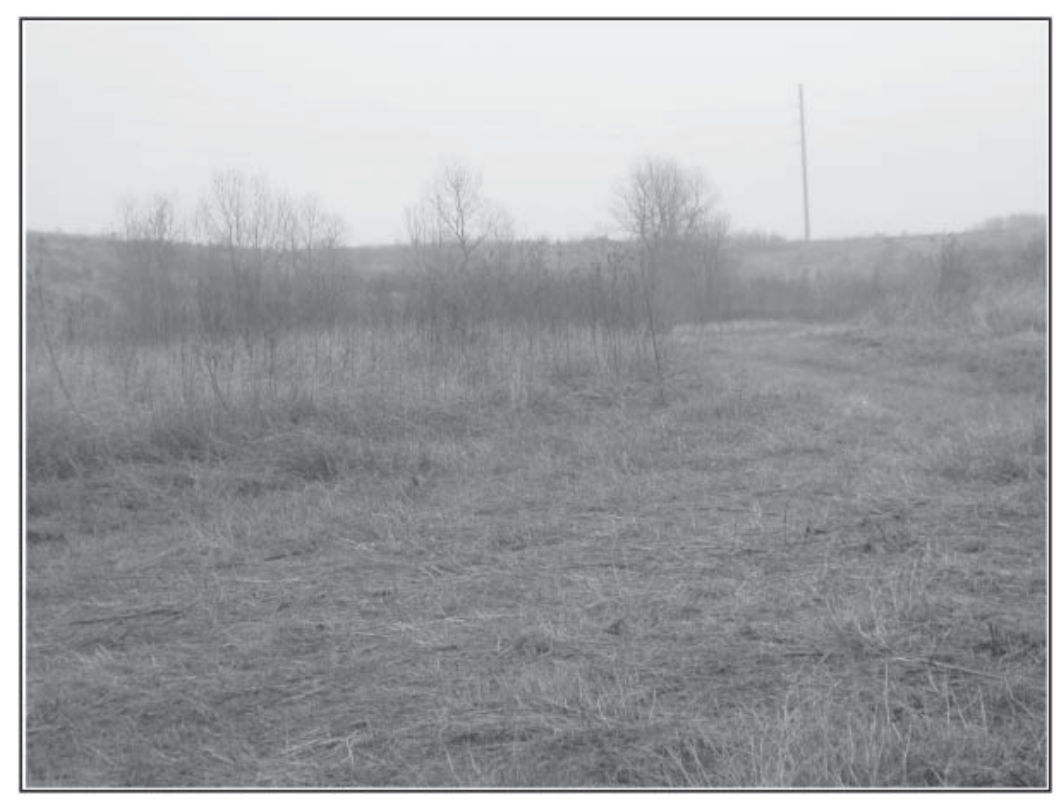

Figure 4-21. Modified portion of 41BX831.

\section{Summary}

CAR's archaeological investigations of the Medina River Park Trail resulted in the excavation of 59 shovel tests and the revisit of eight previously recorded archaeological sites. No new sites were documented during the investigations of the APE. One isolated find was encountered, that consisted of a single piece of flow blue transfer ware in Shovel Test 6 .

The site boundaries of 41BX546 were extended to include surface material to the west. The revisit of 41BX538 included the photo documentation of the standing structures and shovel testing. Shovel tests excavated in the environs of 41BX538 encountered mostly prehistoric material (i.e. burned rock and debitage). Since the boundaries that demarcate 41BX538 and 41BX537 are not distinct, the prehistoric material will be included as part of 41BX538. Revisit TexSite forms of the site were submitted to the Texas Archeological Research Laboratory (TARL).

During the revisit of 41BX533 cultural material was observed on the site surface that included burned rock, debitage and mussel shell fragments. Cultural material recovered from shovel tests included white earthen ware, burned rock, mussel shell fragments and debitage. The one shovel test excavated in the environs of 41BX531 produced a piece of debitage. Recent use of the area by the American Indians in Texas at the Spanish Colonial Missions was documented at 41BX531. Shovel testing at the remaining sites were negative for cultural material. 



\section{Chapter 5: Conclusions and Recommnedations}

In January 2008, CAR conducted a 100 percent intensive pedestrian survey of the Phase II portion of the proposed Medina River Park Trail. The purpose of the pedestrian survey was to identify all prehistoric and historic properties that may be impacted by the proposed trail alignment and determine the NRHP and SAL eligibility status of the portion of the sites that will be impacted by the proposed trail. Impacts that will occur along the APE are minimal in depth $(24 \mathrm{~cm})$. During the course of the intensive pedestrian survey eight previously recorded archaeological sites were revisited and no new sites were identified.

A total of 59 shovel tests were excavated during the survey of the proposed trail. Twenty-eight of the shovel tests were excavated within the boundaries of previously recorded sites. The revisited sites included 41BX531, 41BX538, 41BX833, 41BX831, 41BX533, 41BX537, 41BX545, and 41BX546. We recommend extending the site boundaries of 41BX546 west to include surface artifacts. Current land use of the area by the American Indians in Texas at the Spanish Colonial Missions (AIT-SCM) was documented in the environs of 41BX531. The use of the land for activities, particularly traditional Native American activities should be regulated and avoidance of cultural resources should be attempted and documented here and on other recorded sites where such activities may occur.
Three of the sites revisited by CAR had been designated as SAL's (41BX538, 41BX833 and 41BX831). During the revisit of 41BX538, all structures were photographed and mapped. Two pigeon coops were relocated from 41BX681. Although the proposed trial will not be impacting the structures on 41BX538, they will be visible to pedestrians. To avoid vandalism, periodic monitoring of the structures is recommended.

Shovel tests excavated within the boundaries of 41BX833 and 41BX831 did not contain cultural material. Furthermore, 41BX831 has been heavily modified by land use activities. CAR recommends that the portions of the three sites, which will be impacted by the proposed trail, do not contribute to their SAL status. We recommend that the construction of the proposed Medina River Park trail proceed as planned. However, if any future impacts are foreseen in portions of the SAL sites that were not revisited during these investigations, further work is recommended. Furthermore, if the construction of the trail leads to future secondary impacts (e.g. erosion) below the depths tested during this project, it is recommended that such areas be inspected by professional archaeologists to determine whether deeply buried cultural deposits are impacted. 



\section{References Cited}

Adovasio, J. M. and M. M. Green

2003 Historic Archaeological Investigations in the Applewhite Reservoir Project Area, Bexar County, Texas. Report of Investigation No. 6. Center for Ecological Archaeology. Texas A \& M University, College Station.

Barile, K. S. and K. A. Miller

2003 Archaeological Testing at Site 41BX661, Applewhite South Expansion Project, Bexar County, Texas. SWCA Cultural Resource Report No. 03-284. SWCA Environmental Consultants, Austin.

Barile, K. S., T. Skoglund and K.A. Miller

2003 Cultural Resource Survey of the Applewhite South (Loop 1604 to Watson Road) Expansion Project, Bexar County, Texas. SWCA Cultural Resource Report No. 03-150. SWCA Environmental Consultants, Austin.

Bauer, J.

1974 The Mexican War, 1846-1848. Macmillan, New York.

Bement, L.C.

1989 Excavations at 41BP19: The Kennedy Bluffs Site, Bastrop County, Texas. Texas Archaeological Research Laboratory, The University of Texas at Austin. Contract Reports in Archaeology, Report No. 5, Highway Design Division, Texas State Department of Highways and Public Transportation, Austin.

Black, S.L. and D.G. Creel

1997 The Central Texas Burned Rock Midden Reconsidered. In Hot Rock Cooking on the Greater Edwards Plateau: Four Burned Rock Midden Sites in West Central Texas, by Steve Black, Linda W. Ellis, Darrell G. Creel, and Glenn T. Goode, pp.269-305. Studies in Archeology 2. Texas Archeological Research Laboratory, The University of Texas at Austin.

Bomar, G.

1999 Texas Weather. The University of Texas Press, Austin.

Buckley, E. C.

1911 The Aguayo Expedition into Texas and Louisiana, 1719-1722. Quarterly of the Texas State Historical Association $\mathrm{XV}(1): 1-65$.

Buerkle, R. C.

1976 The Continuing Military Presence. In San Antonio in the 18th Century. San Antonio Bicentennial Heritage Committee.

Chipman, D.E.

1992 Spanish Texas, 1519-1821. University of Texas Press, Austin.

Collins, M.B.

1995 Forty Years of Archeology in Texas. Bulletin of the Texas Archeological Society 66:361-400. 
Cox, I.W.

2005 Appendix D: History of the "Priest’s House” on Military Plaza. In Test Excavations and Monitoring at 41BX1598: A Multicomponent Historic Site in Bexar County, Texas. Archaeological Report, No. 360. Center for Archaeological Research, The University of Texas at San Antonio.

Figueroa, A.L. and S.A. Tomka

2004 Archaeological Survey of the Proposed Medina River Park, Bexar County Texas. Archaeological Survey Report, No. 345. The Center for Archaeological Research, The University of Texas at San Antonio.

Fox, A.A.

1997 Test Excavations at the Spanish Governor's Palace, San Antonio, Texas. Archaeological Survey Report, No. 259. The Center for Archaeological Research, The University of Texas at San Antonio.

Fox, A.A., M. Renner, and R. J. Hard

1997 Archaeology at the Alamodome: Investigations of a San Antonio Neighborhood in Transition, Volume III: Artifacts and Special Studies. Archaeological Survey Report, No. 238. Center for Archaeological Research, The University of Texas at San Antonio.

Fox, A.A. and I.W. Cox

2000 Archaeological Monitoring for Exterior Lighting and Test Excavations at Mission San Juan Capistrano, Bexar County, Texas. Letter Report, No. 131. Center for Archaeological Research, The University of Texas at San Antonio.

Greaves, R.D., J.D. Weston, S.A. Tomka, I.W. Cox, R.B. Mahoney, B.K. Moses, J. Neel-Hartman, and S.A. Wagner 2004 Archaeology of the Planned Location of the Toyota Motor Manufacturing Plant, San Antonio, Bexar County, Texas. Regional Studies 1. The Center for Archaeological Research, The University of Texas at San Antonio.

Hall, G.D., T.R. Hester, and S.L. Black

1986 The Prehistoric Sites at Choke Canyon Reservoir, Southern Texas: Results of the Phase II Archaeological Investigations. Choke Canyon Series, No. 10. Center for Archaeological Research, The University of Texas at San Antonio.

Hester, T.R.

1975 Archaeological and Historical Resources in the San Antonio-Guadalupe River Basins: A Preliminary Statement. The Center for Archaeological Research, The University of Texas at San Antonio.

1995 The Prehistory of South Texas. Bulletin of the Texas Archeological Society 66:427-459.

Hoffman, F.L. (translator)

1937 Diary of the Alarcón Expedition into Texas, 1718-1719. Quivira Society Publications 45:39.

Inman, B.J., T.C. Hill, Jr., and T.R. Hester

1998 Archeological Investigations at the Tortugas Flat Site, 41ZV155, Southern Texas. Bulletin of Texas Archeological Society 69:11-33. 
Mauldin, R., D. L. Nickels, and C. J. Broehm

2003 Archaeological Testing to Determine the National Register Eligibility Status of 18 Prehistoric Sites on Camp Bowie, Brown County, Texas. Archaeological Survey Report, No. 334. Center for Archaeological Research, The University of Texas at San Antonio.

Mauldin, R., B. K. Moses, R. D. Greaves, S. A. Tomka, J. P. Dering and J. D. Weston

2004 Archeological Survey and Testing of Selected Prehistoric Sites along FM 48, Zavala County, Texas. Archaeological Survey Report, No. 352, Center for Archaeological Research, The University of Texas at San Antonio, and Archeological Studies Program, Report No. 67, Environmental Affairs Division, Texas Department of Transportation, Austin.

Mauldin, R. and L. Kemp

2005 An Initial Summary of Bison Presence/Absence associated with Data Recovery at 41ZV202. Report on file at the Center for Archaeological Research, The University of Texas at San Antonio.

Mauldin, R., J. L. Thompson, and L. Kemp

2006 Bison, Bowls, and Bunnies. Paper presented at the 82nd Society for American Archaeology Annual Meeting, Austin.

McGraw, J.A. and K.Hindes

1987 Chipped Stone and Adobe: A Cultural Resources Assessment of the Proposed Applewhite Reservoir, Bexar County, Texas. Archaeological Survey Report, No. 163. The Center for Archaeological Research, The University of Texas at San Antonio.

McKinney, W.W.

1981 Early Holocene Adaptations in Central and Southern Texas: The Problem of the Paleoindian-Archaic Transition. Bulletin of the Texas Archaeological Society 52:91-120.

Meltzer, D.J. and M.R. Bever

1995 Paleoindians of Texas: An Update on the Texas Clovis Fluted Point Survey. Bulletin of the Texas Archeological Society 66:47-81.

Moorehead, M.

1991 The Presidio: Bastion of the Spanish Borderlands. University of Oklahoma Press, Norman.

Nance, J.M.

2004 Republic of Texas. The Handbook of Texas Online, http://www.tshaonline.org/handbook/online/articles/RR/mzr2. html, accessed May 12, 2008.

Nickels, D.L. and R.P. Mauldin

2001 The Project Environment. In An Archaeological Survey of Twin Buttes Reservoir, Tom Green County, Texas, edited by R. Mauldin and D.L. Nickels, pp25-38. Archaeological Survey Report, No. 300, Center for Archaeological Research, The University of Texas at San Antonio.

Perttula, T.K., M.R. Miller, R.A. Ricklis, D.J. Prikryl, and C. Lintz 1995 Prehistoric and Historic Aboriginal Ceramics in Texas. Bulletin of the Texas Archeological Society 66:175-235. 
Ricklis, R.A.

1992 The Spread of the Late Prehistoric Bison Hunting Complex: Evidence from the South-Central Coastal Prairie of Texas. Plains Anthropologist 37(140):261-273.

Story, D.A.

1985 Adaptive Strategies of Archaic Cultures of the West Gulf Coastal Plain. In Prehistoric Food Production in North America, edited by R.I. Ford, pp. 19-56. Anthropological Papers No. 75. Museum of Anthropology, University of Michigan, Ann Arbor.

Taylor, F.B., R.B. Hailey, and D.L. Richmond

1991 Soil Survey of Bexar County, Texas. United States Department of Agriculture, Soil Conservation Service. Washington, D.C.

THC (Texas Historical Commission)

2008 Texas Archaeological Sites Atlas, http://www.nueces.thc.state.tx.us, accessed May 12, 2008.

Thoms, A.V. and R.D. Mandel

2005 Archaeological and Paleoecological Investigations at the Richard Beene Site 41BX831-South-Central Texas. Reports of Investigations 8. Center for Ecological Archaeology, Texas A\&M University, College Station.

Turner, S. E., and T. R. Hester

1992 Stone Artifacts of Texas Indians. Second Edition. Texas Monthly and Gulf Publishing Company, Houston.

Wade, M.

2003 The Native Americans of the Texas Edwards Plateau, 1582-1799. The University of Texas Press, Austin.

Wallace, E.

1965 Texas in Turmoil: The Saga of Texas, 1849-1875. Steck-Vaughn, Austin.

Weddle, R.S.

1968 San Juan Bautista: Gateway to Spanish Texas. The University of Texas Press, Austin.

Weston, J.D.

2004 The Perez Ranch Project: Reassessment of Four Archaeological Sites in South-Central Bexar County, Texas. Archaeological Survey Report, No. 346. The Center for Archaeological Research, The University of Texas at San Antonio.

Wolff, E.

2008 Applewhite Bears More Fruit. San Antonio Current 9 January, San Antonio. 